\title{
Nierówności w produkcji wiedzy naukowej - rola najbardziej produktywnych naukowców w 11 krajach europejskich
}

\begin{abstract}
STRESZCZENIE. W niniejszym tekście skupiamy się na nierównościach w produkcji wiedzy naukowej i pokazujemy, że rozkład indywidualnych wzorców produktywności badawczej w systemach europejskich jest uderzająco podobny mimo odmiennych krajowych tradycji akademickich. Naukowcy znajdujący się na szczycie skali produktywności (górne 10\% badaczy, którzy zajmują najwyższe miejsca pod względem produktywności publikacyjnej w 11 krajach europejskich) dostarczają średnio niemal połowę całej produkcji naukowej w swoich krajach. Nie inaczej jest w Polsce. Wychodząc od podobieństwa wzorców rozkładu produktywności w systemach europejskich, stawiamy ogólne pytania badawcze: kim są najbardziej produktywni naukowcy oraz jakiego rodzaju instytucjonalne i indywidualne czynniki zwiększają szanse na znalezienie się w ich gronie? Najbardziej produktywni badacze jako osobny sektor profesji akademickiej niezwykle rzadko dotąd stawali się przedmiotem badań naukowych. Ze względu na to, że 1/10 europejskich naukowców produkuje niemal połowę wszystkich wytworów badawczych (a 1/20 wytwarza niemal 1/3), ta grupa zasługuje na większą uwagę. Za cel stawiam sobie zbadanie wąsko rozumianej „europejskiej elity badawczej” z międzynarodowej perspektywy porównawczej. Podczas gdy większość wcześniejszych badań opiera się na modelach wykorzystujących regresję liniową, stosowanych do badania produktywności badawczej, w tym tekście wykorzystujemy model regresji logistycznej, poszukując właściwych dla danych krajów predyktorów stawania się produktywnym badaczem. Podstawowe dane analizowane w tym tekście pochodzą z dwóch dużych globalnych i europejskich projektów badawczych dotyczących profesji akademickiej (Changing Academic Profession - CAP oraz Academic Profession in Europe - EUROAC), obejmujących próbę liczącą 17211 obserwacji. Dane odnoszą się do zachowań i postaw naukowców oraz produktywności badawczej subpopulacji najbardziej produktywnych naukowców (górne 10\%, $n=1583$ ), w odróżnieniu do subpopulacji pozostałych 90\% naukowców $(n=12325)$; w obu przypadkach zbiorowością są wyłącznie naukowcy, którzy zadeklarowali zaangażowanie w prowadzenie badań naukowych.
\end{abstract}

SŁOWA KLUCZOWE: produktywni naukowcy, produktywność badawcza, europejska kadra akademicka, stratyfikacja w nauce, produkcja wiedzy, europejska elita badawcza 


\section{Wprowadzenie}

W niniejszym tekście skupiamy się na nierównościach w produkcji wiedzy naukowej i pokazujemy, że rozkład indywidualnych wzorców produktywności badawczej w systemach europejskich jest uderzająco podobny mimo odmiennych krajowych tradycji akademickich. Naukowcy znajdujący się na szczycie skali produktywności (górne 10\% badaczy, którzy zajmują najwyższe miejsca pod względem produktywności publikacyjnej w 11 krajach europejskich) dostarczają średnio niemal połowę całej produkcji naukowej w swoich krajach. Nie inaczej jest w Polsce. Wychodząc od podobieństwa wzorców rozkładu produktywności w systemach europejskich, stawiam w tym tekście ogólne pytania badawcze: Kim są najbardziej produktywni naukowcy oraz jakiego rodzaju instytucjonalne i indywidualne czynniki zwiększają szanse na znalezienie się $\mathrm{w}$ ich gronie?

Najbardziej produktywni badacze jako osobny sektor profesji akademickiej niezwykle rzadko dotąd stawali się przedmiotem badań naukowych. Ze względu na to, że 1/10 europejskich naukowców produkuje niemal połowę wszystkich wytworów badawczych (a 1/20 wytwarza niemal 1/3), grupa ta zasługuje na większą uwagę. Wychodząc od nielicznych wcześniejszych badań skupiających się (w różnym stopniu i z wykorzystaniem różnych podejść metodologicznych) na tym zagadnieniu (de Solla Price 1963; Crane 1965; Prpić 1996; Abramo, D’Angelo i Caprasecca 2009; Postiglione i Jung 2013; Marquina i Ferreiro 2015), za cel stawiam sobie zbadanie wąsko rozumianej „europejskiej elity badawczej” z międzynarodowej perspektywy porównawczej. Poszukiwaliśmy zatem sposobu na empiryczne sprawdzenie oczekiwań wynikających z wcześniejszych badań przeprowadzonych w poszczególnych krajach.

Większość tradycyjnych studiów produktywności badawczej opiera się na badaniach ankietowych przeprowadzonych $\mathrm{w}$ danym kraju czy na wywiadach z przedstawicielami wybranych obszarów nauki - Diane Crane (1965: 700) przebadała amerykańskich biologów, psychologów i politologów, Warren O. Hagstrom (1965: 4) zbadał amerykańskich przedstawicieli nauk medycznych, Jonathan R. Cole i Stephen Cole (1973: 264) zajmowali się amerykańskimi fizykami, a Jerry Gaston (1978: 56) zbadał brytyjskich i amerykańskich biologów, chemików i fizyków. W przeciwieństwie do tych studiów nasze badania dotyczą wszystkich obszarów nauki i obejmują 11 krajów europejskich.

Analizujemy tu zarówno wewnątrzkrajowe różnice w produktywności badawczej między europejską elitą badawczą a pozostałymi naukowcami zaangażowanymi w badania (czy też „przeciętnymi” naukowcami; por. Stephan i Levin 1992: 5758; Prpić 1996: 185), jak i międzynarodowe różnice i podobieństwa występujące wśród europejskiej elity. Opierając się na wcześniejszych badaniach dotyczących predyktorów wysokiej produktywności badawczej (Allison, Long i Krauze 1982; 
Allison i Stewart 1974; Wanner, Lewis i Gregorio 1981; Fox 1983; Stephan i Levin 1992; Ramsden 1994; Teodorescu 2000; Lee i Bozeman 2005; Leisyte i Dee 2012; Shin i Cummings 2010; Drennan, Clarke, Hyde i Politis 2013), stawiam następujące pytania przewodnie: Czy najbardziej produktywni naukowcy (analizowana w całym tekście, opracowana i zdefiniowana przez nas kategoria top research performers) w Europie współdzielą wzorce dystrybucji czasu pracy oraz modele ról w odniesieniu do kształcenia czy badań, które w literaturze przedmiotu były zawsze połączone z produktywnością badawczą? Czy w całej Europie charakterystyki demograficzne takich badaczy, ich wzorce socjalizacji do norm akademii, umiędzynarodowienie i współpraca zawodowa oraz całościowe zaangażowanie w badania są do siebie podobne? Czy w podobny sposób ujmują oni swoje instytucje? Mówiąc najogólniej, pytamy o to, w jaki sposób bardzo produktywni naukowcy różnią się od „przeciętnych”, w jaki sposób różni ich sposób pracy oraz jej postrzeganie, a także jakie czynniki są pozytywnie skorelowane $\mathrm{z}$ wysoką produktywnością badawczą.

Wykorzystujemy tu trzy uzupełniające się podejścia: statystykę opisową, wnioskowanie statystyczne (m.in. test $t$ dla równości dla dwóch średnich oraz test $z$ dla równości frakcji, wykonane dla dwóch niezależnych prób, zastosowane do niemal uniwersalnych zmiennych z badań produktywności badawczej: dużej liczby godzin poświęconych na badania i wysokiego stopnia ukierunkowania się na badania) oraz wielowymiarowy model regresji logistycznej. Podczas gdy większość wcześniejszych badań opierała się na modelach wykorzystujących regresję liniową stosowanych do badania produktywności badawczej, w tym przypadku wykorzystujemy model regresji logistycznej, poszukując właściwych dla danych krajów predyktorów stawania się produktywnym badaczem. Podstawowe dane tu analizowane pochodzą z dwóch dużych projektów badawczych (globalnego i europejskiego) dotyczących profesji akademickiej (Changing Academic Profession - CAP oraz Academic Profession in Europe - EUROAC), obejmujących próbę liczącą 17211 obserwacji. Dane odnoszą się do zachowań i postaw naukowców oraz produktywności badawczej subpopulacji najbardziej produktywnych naukowców (górne 10\%, $n=1583$ ), w odróżnieniu od subpopulacji pozostałych naukowców (dolne 90\%, $n=12325$ ); w obu przypadkach zbiorowością są wyłącznie naukowcy, którzy zadeklarowali zaangażowanie w prowadzenie badań naukowych.

Ujmując rzecz w skrócie, nierówność w produkcji wiedzy naukowej w Europie wygląda następująco: ok. 10\% naukowców - określanych tu jako „najbardziej produktywni naukowcy" - produkuje średnio niemal połowę $(45,9 \%)$ wszystkich artykułów, a 20\% wytwarza 2/3 publikacji (65,4\%). Pozostałe 80\% naukowców wytwarza 1/3 wszystkich artykułów (34,6\%). Jeśli aktywny badawczo sektor europejskiej kadry akademickiej zostałby podzielony na pół, to okazałoby się, że górna, bardziej produktywna połowa wytwarza niemal wszystkie artykuły (94,1\%), a dolna, mniej produktywna połowa wytwarza ich mniej niż 6\% (5,9\%). 
Niniejszy tekst dostarcza innego, tym razem mocnego i międzynarodowego potwierdzenia nierówności w produkcji wiedzy, o której po raz pierwszy pisali Alfred Lotka (1926) i Derek de Solla Price (1963). Pokazujemy, że tradycyjna stratyfikacja profesji akademickiej oparta na różnych wzorcach intensywności publikacyjnej wciąż ma miejsce w Europie. Pod tym względem nauka w Europie pozostaje niezmieniona, a polskie wzorce nie różnią się od wzorców zachodnioeuropejskich (różni się natomiast istotnie na niekorzyść poziom polskiej produktywności badawczej: por. Kwiek 2015b; Kwiek 2015e; powody skrajnie niskiej produktywności wyjaśniam w: Kwiek 2014a; 2012, poprzez koncepcję systematycznej deinstytucjonalizacji misji badawczej polskich uczelni w latach 1990-2010).

Prezentowany tekst przyjmuje następującą strukturę: kontekst teoretyczny składa się z części poświęconych „teoriom produktywności badawczej”, przeglądowi literatury na temat „wysoce produktywnych naukowców” oraz dylematowi „jakość vs ilość w badaniach produktywności badawczej”. Trzecia część tekstu prezentuje dane i metody badawcze, czwarta - wyniki badań, piąta - dyskusję, a szósta - wnioski.

\section{Kontekst teoretyczny}

\subsection{Teorie produktywności badawczej}

Produktywność badawcza od dłuższego czasu jest przedmiotem namysłu naukowego (pierwsze sformułowania tej problematyki: Crane 1965; de Solla Price 1963; Merton 1968; Cole i Cole 1973). W literaturze przedmiotu dokonano rozpoznania wielu indywidualnych i instytucjonalnych czynników, które wpływają na produktywność badawczą, obejmujących: wielkość wydziału, normy obowiązujące w danej dyscyplinie nauki, systemy nagród i prestiżu oraz różne konstrukcje psychologiczne na poziomie jednostkowym, takie jak pragnienie nagrody związane z rozwiązaniem naukowej zagadki (Leisyte i Dee 2012; Stephan i Levin 1992; Ramsden 1994; Teodorescu 2000). Powszechnie uważa się, że wyższą produktywność badawczą prognozuje ukierunkowanie kadry na badania, a także czas poświęcony na badania, bycie mężczyzną, poziom współpracy międzynarodowej, lata, które upłynęły od zdobycia doktoratu, jak również atmosfera współpracy i wsparcie ze strony zatrudniającej instytucji (Porter i Umbach 2001; Katz i Martin 1997; Smeby i Try 2005; Lee i Bozeman 2005). Istnieje kilka teorii wyjaśniających radykalne różnice w indywidualnej produktywności badawczej; skupimy się tu na teorii iskry bożej, teorii akumulacji przewag (połączonej z teorią wzmocnienia) oraz teorii maksymalizacji korzyści.

Teoria iskry bożej, zaprezentowana przez Jonathana R. Cole'a i Stephena Cole’a (1973), mówi, że „istnieją istotowe, z góry określone różnice między naukowcami dotyczące ich zdolności i motywacji do twórczych badań naukowych” (za: 
Allison i Stewart 1974: 596). Bardzo produktywni badacze „motywowani są przez wewnętrzny pęd do tworzenia nauki oraz przez czystą miłość do pracy" (Cole i Cole 1973: 62). Produktywni naukowcy są silnie zmotywowaną grupą badaczy i mają niezbędną wytrzymałość „czy zdolność do ciężkiej pracy oraz wytrwałość w pogoni za dalekosiężnymi celami” (Fox 1983: 287). Podobnie sądzą Paula Stephan i Sharon Levin (1992: 13): „istnieje ogólna zgoda co do tego, że niektórzy ludzie są szczególnie dobrzy w tworzeniu nauki oraz że niektórzy są nie tyle po prostu dobrzy, ile znakomici”.

Teoria akumulacji przewag (accumulative advantage theory), rozwinięta przez Roberta K. Mertona (1968), głosi, że produktywni naukowcy stają się w przyszłości jeszcze bardziej produktywni, podczas gdy niska produktywność naukowców staje się z czasem jeszcze niższa. Teoria akumulacji przewag powiązana jest z teorią wzmocnienia (reinforcement theory), sformułowaną przez Cole'a i Cole'a (1973: 114), która mówi, że „naukowcy, którzy są wynagradzani, są produktywni, a naukowcy, którzy nie są wynagradzani, stają się mniej produktywni”. Jak wskazał Jerry Gaston (1978: 144), wzmocnienie dotyczy tego, dl a cze g o naukowcy kontynuują działalność badawczą; natomiast akumulowanie przewag dotyczy tego, j a k niektórzy naukowcy są w stanie zdobywać zasoby na swoje badania, które prowadzą do jeszcze bardziej udanych badań i kolejnych publikacji. Niektóre studia (np. Allison i Stewart 1974; Allison, Long i Krauze 1982) wspierają hipotezę akumulacji przewag, nie dyskredytując przy tym hipotezy iskry bożej.

Natomiast według teorii maksymalizacji korzyści wszyscy badacze z czasem dokonują redukcji wysiłków ukierunkowanych na badania, ponieważ uważają, że inne zadania mogą być dla nich osobiście bardziej korzystne. Tak skomentował to Svein Kyvik (1990: 40):

[...] wybitni badacze mogą mieć niewiele zachęt do napisania nowego artykułu czy książki, ponieważ nie polepszają one w istocie świetnej reputacji zawodowej, którą obecnie dysponują.

Paula F. Stephan i Sharon G. Levin (1992: 35), omawiając kwestię wieku, starzenia się i produktywności, twierdzą, że „w późniejszym okresie kariery naukowcy są w mniejszym stopniu finansowo zmotywowani do prowadzenia badań. [...] z każdym dodatkowym rokiem nagroda za ich wykonywanie zmniejsza się". Teoria maksymalizacji korzyści wyjątkowo dobrze pasuje do sytuacji w Polsce - motywacja do prowadzenia badań naukowych była w ostatnich dwóch dekadach niezwykle niska (a motywacja do prowadzenia dodatkowego kształcenia studentów w sektorze prywatnym - wyjątkowo wysoka. Jak pokazują statystyki MNiSW, największy udział w wieloetatowości mieli profesorowie tytularni). Te trzy główne teorie produktywności badawczej są względem siebie komplementarne, a nie konkurencyjne - wszystkie w różnym stopniu stosują się do europejskiej kadry akademickiej, w tym kadry akademickiej w Polsce. 


\subsection{Wysoce produktywni naukowcy - przegląd literatury}

W literaturze przedmiotu występują dwa podejścia do badania wysokiej produktywności badawczej na poziomie indywidualnym. Pierwsze to badania prowadzone na bazie materiału jakościowego - najpierw tworzy się rankingi wysoce produktywnych naukowców, następnie przeprowadza się wywiady z tymi, którzy zajmują w nich czołowe miejsca, zadając ogólne pytanie badawcze typu: „co sprawia, że są oni tak produktywni?” (por. Mayrath 2008: 42). Następnie wyprowadza się różne „klucze do produktywności” (Kiewra i Creswell 2000: 155) czy „wskazówki dotyczące efektywnego publikowania” (Kiewra 1994). Korzysta się tu z ukierunkowanych na poszukiwanie uwarunkowań wysokiej produktywności badań ankietowych pośród produktywnych naukowców, z wywiadów z „wybitnymi” lub „płodnymi” badaczami albo łączy się obie te strategie. Drugim podejściem jest badanie wysokiej produktywności badawczej w sposób ilościowy - poprzez badania ankietowe kadry akademickiej, w których charakterystyki zachowań i postaw są analizowane łącznie z informacjami na temat publikacji. W niniejszym tekście zostanie wykorzystane to drugie, ilościowe podejście.

Podejście jakościowe preferowane jest zaś w takich „miękkich” dyscyplinach, jak psychologia nauczania (Mayrath 2008; Kiewra i Creswell 2000; Patterson-Hazley i Kiewra 2013). Na podstawie zebranego materiału jakościowego można odpowiedzieć na pytanie: ,jakie czynniki określają wysoce produktywnego psychologa nauczania?" (Kiewra i Creswell 2000: 136). Szukając klucza do wysokiej produktywności badawczej, autorzy korzystający z tej metody podają wiele użytecznych porad oraz przedstawiają obrazowe, pojedyncze przykłady. Przyjętą przez nich metodę można streścić następująco: rozmawiamy z wybranymi w drodze rankingu, modelowymi naukowcami pod względem produktywności badawczej, badamy ich życiową drogę do sukcesu, pytamy o codzienne nawyki związane z życiem i pracą i uogólniamy wnioski. Jednak badania jakościowe dotyczące bardzo produktywnych naukowców oparte na przeprowadzonych rozmowach, choć fascynujące, są słabo uteoretyzowane. Nagromadzenie szczegółów nie prowadzi do powstawania nowych teorii produktywności ani do weryfikacji (nielicznych) teorii istniejących.

Produktywność badawcza kadry naukowej była dokładnie analizowana w literaturze przedmiotu, szczególnie w kontekście pojedynczych krajów: USA, Wielkiej Brytanii i Australii (Cole i Cole 1973; Allison i Stewart 1974; Fox 1983; Ramsden 1994), a także Korei Południowej (Shin i Cummings 2010), jednak bardzo rzadko w porównawczym kontekście międzynarodowym, z którego tu korzystamy (wyjątki stanowią: Teodorescu 2000; Drennan i in. 2013; Postiglione i Jung 2013). W tym tekście wykorzystujemy nieistniejące zazwyczaj w tych badaniach pełne 
próby krajowe i odnosimy się do wszystkich obszarów nauk (łącząc je w pięć dużych grup), a nie do wybranych obszarów, najczęściej nauk ścisłych.

Międzynarodowe badania porównawcze szkolnictwa wyższego nie zgłębiały dotąd problematyki specyficznej klasy bardzo produktywnych naukowców; jednak wzmiankowano o nich w kilku pracach poświęconych kadrze akademickiej w pojedynczych krajach (Crane 1965; Cole i Cole 1973; Allison 1980). Wyjątek stanowią tu Mała nauka - wielka nauka Dereka De Solla Price'a (1963) - założycielska książka naukometrii analizująca amerykańskich „dużych wytwórców” wiedzy, a także badanie „gwiazd akademickich” w kontekście różnic płciowych w produktywności badawczej we Włoszech, przeprowadzone przez Giovanniego Abramo, Andreę Ciriaco D’Angelo i Alessandra Capraseccę (2009) oraz badania produktywności chorwackich „wybitnych naukowców” (Prpić 1996). Abramo ze współpracownikami (2009: 143) podsumowują, że gwiazda akademicka to „najczęściej mężczyzna i profesor zwyczajny"; kobiety sytuują się raczej na niższych szczeblach hierarchii produktywności publikacyjnej gwiazd akademickich. Autorzy twierdzą, że „aby osiągnąć poziom naukowej produktywności porównywalny do poziomu uzyskiwanego przez gwiazdy akademickie, wymagane jest poświęcenie czasu i energii na działalność badawczą znacząco większe od średniego oraz pełne oddanie własnej pracy" (Abramo i in. 2009: 154). Jednak, jako że omawiana praca oparta jest na danych bibliometrycznych, autorzy nie są w stanie w swoich badaniach „profilu gwiazd akademickich” wykroczyć poza płeć, stopień naukowy, typ instytucji i dyscyplinę naukową. Z kolei Katarina Prpić (1996) porównywała produktywność naukową „,wybitnych” oraz „przeciętnych” naukowców. Jej założenia badawcze stanowily, że wzorce predyktorów wysokiej produktywności publikacyjnej wybitnych naukowców będą różnić się od tych właściwych „przeciętnym” naukowcom, ponieważ w pierwszej, elitarnej grupie „homogeniczność jest większa, a zróżnicowanie mniejsze niż w całej badanej populacji” (Prpić 1996: 199).

W ostatnim czasie Gerard Postiglione i Jisun Jung (2013) przebadali „badaczy z najwyższego poziomu” (top-tier researchers) z czterech krajów azjatyckich, poszukując ich podobieństw według badania CAP. Zbadali 10\% najbardziej produktywnych oraz 10\% najmniej produktywnych naukowców za pomocą metod opisu statystycznego. Odkryli w ten sposób, że bardzo produktywni naukowcy częściej kładą nacisk na odkrycia, badania podstawowe/teoretyczne oraz społeczną odpowiedzialność $\mathrm{w}$ nauce niż pozostali naukowcy, a także spędzają więcej czasu na badaniach niż na kształceniu. Znacznie częściej niż inni współpracują, szczególnie w obszarze międzynarodowym, jak również postrzegają swoje instytucje jako te, które podejmują decyzje dotyczące personelu i alokacji środków finansowych na podstawie kryteriów opartych na wynikach (Postiglione i Jung 2013: 171-177). Monica Marquina i Mariela Ferreiro (2015), również bazując na CAP, zbadały specyficzną „elitarną grupę” naukowców w sześciu krajach rozwijających się. Porównały „elitarne grupy” (elite groups) z „pozostałymi” naukowcami (the rest). Skupiły się 
na elitach akademickich określonych jako naukowcy z doktoratem, zatrudnieni na pełen etat, poświęcający ponad dziesięć godzin tygodniowo na badania i preferujący badania, a nie kształcenie. Chociaż kategoria „elitarnych grup” nie odnosi się w omawianym studium bezpośrednio do kwestii produktywności naukowej, to zachodzą istotne paralele z naszymi badaniami. Naukowcy „elitarnych grup” są bardziej umiędzynarodowieni zarówno pod względem kształcenia studentów, badań naukowych, jak i wzorców publikowania; są również bardziej zadowoleni ze swojej pracy; mocniej ukierunkowani na badania i poświęcają im więcej czasu (Marquina i Ferreiro 2015: 191). Najważniejsze teorie produktywności badawczej oraz badania dotyczące bardzo produktywnych naukowców, jakkolwiek rzadkie i o ograniczonym zasięgu geograficznym i dyscyplinarnym, stanowią konceptualną podstawę niniejszego tekstu.

\subsection{Dylemat jakość vs. ilość w badaniach nad produktywnością badawczą}

Nie twierdzimy, że liczba publikacji (tu: artykułów z recenzowanych czasopism oraz rozdziałów z monografii, wyłączając książki) jest najlepszym sposobem pomiaru naukowej produktywności badawczej dla celów międzynarodowych porównań; nie próbujemy również wiązać publikacji z ich wartością, obecną lub przyszłą (podobnie jak standardowo nie dokonuje się powiązań cytowań z ich wartością, obecną lub przyszłą), czy też z prestiżem czasopism, w których zostały opublikowane. Zgodnie z wcześniejszymi badaniami dotyczącymi produktywności publikacyjnej zakładamy, podążając za Mary Frank Fox (1983: 285), że głównym środkiem komunikacji w nauce jest proces publikacyjny: „to poprzez publikacje naukowcy uzyskują zawodowe uznanie oraz szacunek, jak również awanse i finansowanie na przyszłe badania”. „Uznanie” w nauce pochodzi z „dorobku naukowego” (Cole i Cole 1967), a system nagród opracowany jest w taki sposób, by obdarzać uznaniem i szacunkiem tym naukowców, którzy w najlepszy sposób wypełniają swoje role. Według Roberta K. Mertona (1973: 297) ,instytucje nauki rozwinęły zaawansowany system przyznawania nagród tym, którzy w różny sposób pozostają wierni ich normom". Publikacje oraz cytowania mają coraz większe znaczenie i w tym wypadku właściwe pytanie, jak w swojej książce o systemach nagród wyłożył to Jerry Gaston (1978: ix), brzmiałoby: „Czy ludzie otrzymują to, na co zasługują, czy też nie?”. Naukowcy publikują swoje prace w zamian za środowiskowe, akademickie uznanie. Jak głosi teoria społecznej kontroli w nauce Warrena O. Hagstroma (1965: 168): „uznanie udzielane jest za informacje, a naukowiec, który dzieli się dużą liczbą informacji ze swoimi kolegami, wynagradzany jest przez nich wysokim prestiżem”. Analizy produktywności badawczej znajdują się więc w samym sercu badań kadry akademickiej. 
W niniejszym tekście spośród informacji pochodzących z baz CAP/EUROAC wykorzystano wskaźniki deklarowanej liczby publikacji za 3 lata poprzedzające rozesłanie ankiety. Nie istniała techniczna możliwość połączenia liczby publikacji z liczbą cytowań, ani w kontekście całkowitej próby 13908 europejskich naukowców zaangażowanych w badania, ani podpróby 1583 „najbardziej produktywnych naukowców". Anonimizacja wszystkich 11 krajowych baz danych poprzedzająca ich połączenie w jedną europejską bazę danych wykluczyła badanie jakiejkolwiek korelacji opartej na wpływie na naukę mierzonym liczbą cytowań (co można zrobić osobno dla niektórych krajowych systemów dysponujących specyficznymi bazami danych, powstającymi najczęściej wskutek przeprowadzania krajowych programów ewaluacji badań; zob. studium Abramo, D’Angelo i Caprasecca 2009 dla całej populacji włoskich naukowców).

Dylemat związany z problemem ilość vs. jakość w badaniach produktywności akademickiej opartych na liczbie publikacji nie daje się łatwo rozstrzygnąć. W niniejszym tekście przyjmujemy, że bardziej produktywni naukowcy publikują więcej artykułów niż mniej produktywni, jednak nie wiążemy tak rozumianej produktywności ani z oryginalnością artykułów, ani z ich obecnym lub przyszłym wpływem na dyscypliny naukowe oraz poza nimi - na naukę czy społeczeństwo.

W badaniu stratyfikacji społeczności fizyków (opartym zarówno na ilości, jak i jakości publikacji) Cole i Cole (1973: 91-93) wyodrębnili cztery typy idealne akademickiej produkcji badawczej: „badaczy płodnych” (prolific), „perfekcjonistów”, „masowych wytwórców” oraz badaczy „,cichych” (czyli tak w Polsce rozpowszechnionych silent scientists). Koncentrujemy się tu na pierwszym z tych typów - badaczach płodnych, charakteryzowanych zarówno poprzez dużą liczbę, jak i wysoką jakość publikacji. Jak stwierdzili Cole i Cole (1973: 111): „ponieważ jakość i wielkość dorobku badawczego są ze sobą dość silnie skorelowane, ci, którzy wytwarzają dużo, mają ten den cję do publikowania bardziej istotnych badań [...] zaangażowanie w dużą liczbę badań jest w pewnym sensie warunkiem »koniecznym « dla produkcji prac dobrej jakości”. Podobnie twierdzą Stephan i Levin (1992: 364): płodni naukowcy, których badały, nie „osiągali wysokich wyników ilościowych poprzez utratę jakości wskutek publikowania w czasopismach, które mają mniejszy wpływ”. W tym samym duchu wypowiada się także Price (1963: 41): „chociaż nie ma żadnej gwarancji, że ktoś, kto wytwarza niewiele, jest nikim, a ktoś, kto wytwarza dużo, jest renomowanym naukowcem, to istnieje tu silna korelacja”. Nasze badanie wykorzystuje rozbudowaną, międzynarodową bazę danych dotyczącą kadry akademickiej, uwzględniając właściwe jej ograniczenia (Teichler, Arimoto i Cummings 2013: 35). 


\section{Dane i metody badawcze}

\subsection{Dane}

Analizujemy tu produktywność badawczą, określoną przez Daniela Teodorescu (2000: 206) jako „deklarowana liczba artykułów w czasopismach naukowych oraz rozdziałów w monografiach naukowych, które respondent opublikował w ciągu 3 lat poprzedzających przeprowadzenie badania ankietowego". Zmienną zależną, którą badamy, jest przynależność do europejskiej elity badawczej (wyodrębnionej według kryterium liczby publikacji określonego wyżej typu z lat 2007-2010). Nasze dane pochodzą z krajów zaangażowanych w projekty badawcze CAP i EUROAC. Badaliśmy w tym tekście bardzo produktywnych naukowców pracujących w ramach różnych krajowych systemów, począwszy od tych o najniższych wynikach (Polska), a skończywszy na tych o wynikach najwyższych (Włochy, Holandia) (zob. złożone indeksy krajów dla produktywności badawczej pełnoetatowych pracowników akademickich zatrudnionych w sektorze uniwersyteckim: Kwiek 2015e) ${ }^{1}$.

\subsection{Metody}

W celu zbadania wysoce produktywnych naukowców podzieliliśmy próbę wszystkich europejskich naukowców na dwie podpróby: naukowców deklarujących zaangażowanie w badania i tych, którzy tego zaangażowania nie deklarują. Następnie podpróbę naukowców zaangażowanych $\mathrm{w}$ badania podzieliliśmy na dwie kolejne grupy: pierwszą z nich była grupa „najbardziej produktywnych naukowców” (research top performers), utożsamianych z naukowcami, którzy zajmują miejsce w grupie 10\% (na ile pozwala na to liczba publikacji - w większości przypadków nie da się wybrać kadry na poziomie dokładnie 10\%) uczonych o najwyższej produktywności badawczej w każdym z 11 krajowych systemów (osobno) oraz we wszystkich pięciu głównych grupach obszarów badań (osobno). Drugą grupę stanowiło pozostałe 90\% naukowców zaangażowanych w badania. Rozkład populacji w próbie według kraju został ukazany w tabeli 1; obejmuje on liczbę obserwacji przydatnych w obecnym badaniu (tj. zawierających wszystkie niezbędne dane):

1 Pracowaliśmy na zbiorze danych z 17 czerwca 2011 r. opracowanym przez René Kooija i Floriana Löwensteina z International Centre of Higher Education and Research (INCHER-Kassel). Projekt EUROAC, w którym kierowaliśmy polskim zespołem badawczym, był projektem EUROCORES EuroHESC, koordynowanym przez European Science Foundation w latach 2009-2013 (a jego uczestnikiem był również dr Dominik Antonowicz z UMK w Toruniu, odpowiedzialny głównie za przeprowadzenie wywiadów z polską kadrą akademicką i kierowanie zbieraniem danych statystycznych przez Ośrodek Przetwarzania Informacji w Warszawie). Koordynatorem naukowym projektu EUROAC był Ulrich Teichler z INCHER, natomiast projektu CAP - William Cummings z George Washington University. 
liczbę naukowców zaangażowanych w aktywności badawcze ( $n$ ), udział naukowców zaangażowanych w badania naukowe, liczbę ankiet najbardziej produktywnych naukowców oraz udział najbardziej produktywnych naukowców w populacji próby naukowców zaangażowanych w badania (przyjmując, że jest to ok. 10\%). Szczególnie istotne są międzynarodowe różnice w udziale naukowców zaangażowanych w badania naukowe w systemach krajowych: na jednym biegunie sytuują się kraje (np. Polska, Włochy, Norwegia), w których niemal wszyscy zbadani naukowcy deklarowali, że są zaangażowani w badania (blisko 98-99\% w dwóch pierwszych, a w Norwegii ok. 90\%); na drugim natomiast kraje (np. Holandia, Wielka Brytania), w których takie zaangażowanie deklaruje jedynie połowa badanych, w związku z inną strukturą zatrudnienia w szkolnictwie wyższym, a zwłaszcza z istnieniem stanowisk dydaktycznych. Pozostałe 7 krajów znajduje się bliżej środka skali, ze średnią dla 11 krajów na poziomie ok. 80\%.

Tabela 1. Rozkład próby według kraju

\begin{tabular}{|l|r|r|r|r|c|}
\hline \multirow{2}{*}{ Kraj } & \multirow{2}{*}{ Suma } & \multicolumn{2}{|c|}{ Zaangażowani w badania } & \multicolumn{2}{c|}{ Najbardziej produktywni naukowcy } \\
\cline { 3 - 6 } & & $N$ & $\%$ & $N$ & $\%$ \\
\hline Austria & 1492 & 1297 & 86,9 & 146 & 11,3 \\
\hline Finlandia & 1374 & 1063 & 77,4 & 126 & 11,9 \\
\hline Niemcy & 1215 & 1007 & 82,9 & 110 & 10,9 \\
\hline Irlandia & 1126 & 865 & 76,8 & 101 & 11,7 \\
\hline Włochy & 1711 & 1674 & 97,8 & 191 & 11,4 \\
\hline Holandia & 1209 & 536 & 44,3 & 61 & 11,4 \\
\hline Norwegia & 986 & 876 & 88,8 & 106 & 12,1 \\
\hline Polska & 3704 & 3659 & 98,8 & 411 & 11,2 \\
\hline Portugalia & 1513 & 944 & 62,4 & 104 & 11,0 \\
\hline Szwajcaria & 1414 & 1210 & 85,6 & 138 & 11,4 \\
\hline Wlk. Brytania & 1467 & 777 & 53,0 & 89 & 11,5 \\
\hline Suma & 17211 & 13908 & 80,8 & 1583 & 11,4 \\
\hline
\end{tabular}

Źródło: opracowanie własne.

Najbardziej produktywni naukowcy tworzą rdzeń europejskiej produkcji badawczej - bez nich zmniejszyłaby się ona o połowę, ponieważ średnio, zgodnie we wszystkich zbadanych systemach europejskich, nieco mniej niż połowa (46\%) całej produkcji naukowej mierzonej liczbą artykułów w recenzowanych czasopismach naukowych (i monografiach) pochodzi od ok. 10\% najbardziej produktywnych naukowców. W czterech systemach ich udział zbliża się lub przekracza 50\% (Austria, Finlandia, Polska oraz Portugalia). W reprezentatywnej próbie europejskiej 17211 naukowców z 11 systemów próba cząstkowa 1583 bardzo produktywnych naukowców wytworzyła 32706 spośród 71248 (45,9\%) artykułów w czasopismach naukowych (i monografiach) w badanym okresie 3 lat (por. tab. 2 i wykres 
Tabela 2. Liczba i odsetek artykułów naukowych (deklarowanych w próbie) opublikowanych w ciągu 3 lat przez najbardziej produktywnych naukowców i pozostałych naukowców, według kraju

\begin{tabular}{|l|c|c|c|c|}
\hline \multirow{2}{*}{ Kraj } & \multicolumn{2}{|c|}{ Liczba artykułów naukowych } & \multirow{2}{*}{$\begin{array}{c}\text { Odsetek } \\
\text { artykułów naukowych: } \\
\text { najbardziej produktywni } \\
\text { naukowcy }\end{array}$} \\
\hline $\begin{array}{c}\text { najbardziej } \\
\text { produktywni } \\
\text { naukowcy }\end{array}$ & $\begin{array}{c}\text { pozostali } \\
\text { naukowcy }\end{array}$ & razem & 73,4 \\
\hline Austria & 3330 & 1206 & 4536 & 50,1 \\
\hline Finlandia & 2445 & 2435 & 4880 & 43,5 \\
\hline Niemcy & 2702 & 3506 & 6208 & 47,4 \\
\hline Irlandia & 2419 & 2684 & 5103 & 33,4 \\
\hline Włochy & 5096 & 10162 & 15259 & 47,9 \\
\hline Holandia & 1513 & 1647 & 3160 & 44,8 \\
\hline Norwegia & 1902 & 2340 & 4243 & 49,8 \\
\hline Polska & 6767 & 6831 & 13599 & 50,5 \\
\hline Portugalia & 1992 & 1952 & 3945 & 45,9 \\
\hline Szwajcaria & 2798 & 3304 & 6102 & 41,3 \\
\hline Wlk. Brytania & 1740 & 2475 & 4215 & 45,9 \\
\hline Suma & 32706 & 38543 & 71248 & \\
\hline
\end{tabular}

Źródło: opracowanie własne.

Wykres 1. Odsetek artykułów napisanych przez najbardziej produktywnych naukowców w całej produkcji naukowej, według kraju

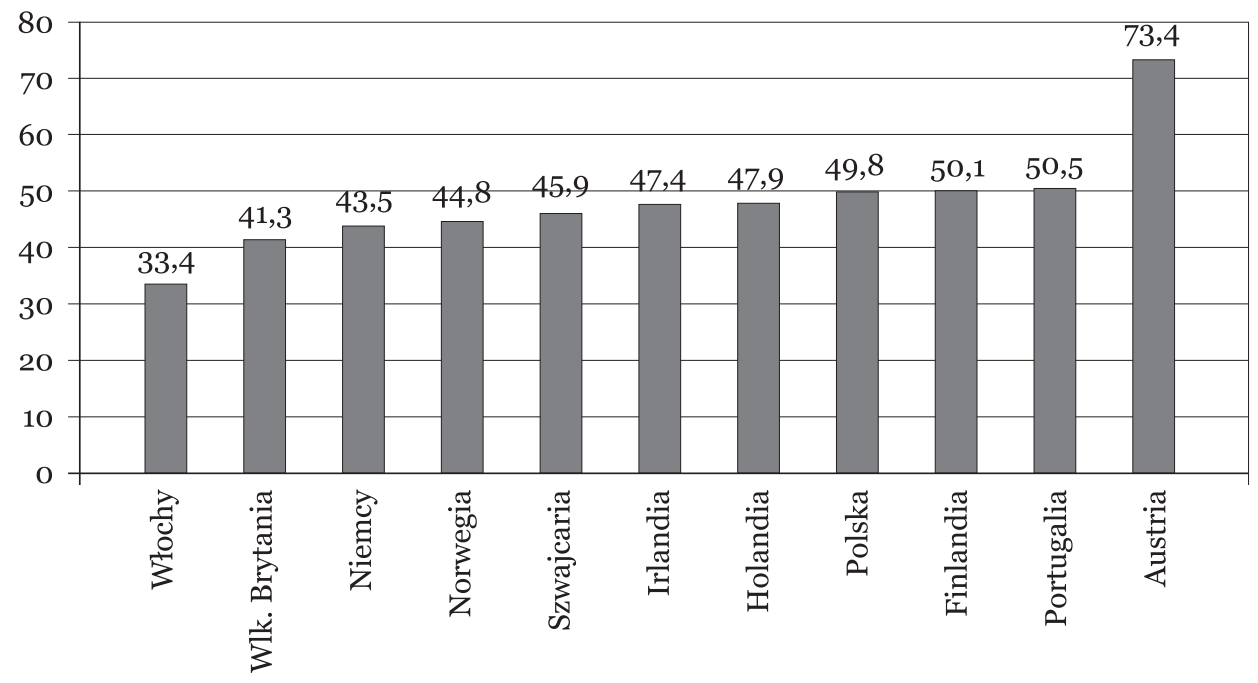

Źródło: opracowanie własne. 
1). Grupa 5\% najbardzo produktywnych naukowców wykazuje podobieństwa do wzorca europejskiego: wytworzyli oni średnio 33\% wszystkich artykułów).

Obierając zgodne wzorce rozkładu produktywności przedstawione wyżej za punkt wyjścia dla naszych badań, omówimy najbardziej produktywnych naukowców na drodze dwuzmiennej analizy rozkładu czasu pracy oraz orientacji na role związane z kształceniem i badaniami. Zastosujemy tu wnioskowanie statystyczne wykorzystujące testy $t$ dla równości średnich oraz testy $z$ dla równości frakcji. Test $t$ dla prób niezależnych stosowany jest wtedy, gdy chcemy porównać średnie w dwóch niezależnych populacjach (najbardziej produktywnych naukowców oraz pozostałych naukowców) - poprzez wykorzystanie informacji z próby testujemy, czy średni czas poświęcony różnym kategoriom działań naukowych jest równy dla obu populacji naukowców. Test $z$ na równość frakcji wykorzystany został do zweryfikowania hipotezy mówiącej, że dwie wyodrębnione populacje (najbardziej produktywnych naukowców oraz pozostałych naukowców) mają równe proporcje. Chociaż analizy dwuwymiarowe cechują pewne ograniczenia, ponieważ nie kontroluje się innych istotnych czynników, które mogą wpłynąć na produktywność badawczą (Teodorescu 2000: 203), dwie wybrane zmienne pojawiają się jako kluczowe w większości jakościowych i ilościowych badań produktywności. Wymagają zatem osobnego potraktowania.

Jako że badanie wielowymiarowych relacji wymaga podejścia modelowego, zaprezentowany zostanie iloraz szans oszacowany za pomocą modelu regresji logistycznej dla przynależności do europejskiej elity badawczej, poprzedzony metodami wnioskowania statystycznego. Te ostatnie, jak również analizy oparte na regresji logistycznej, postrzegane są jako komplementarne - oba podejścia są użyteczne w realizacji celów stojących przed naszym badaniem.

Mówiąc dokładnie: w części poświęconej podziałowi czasu zastosowano test $t$ dla dwóch prób niezależnych. Gdy wariancja w porównanych populacjach jest równa (wykorzystujemy tu test homogeniczności wariancji Levene’a), wówczas stosowany jest $t$-test Studenta; w przeciwnym przypadku stosowany jest test $t$ dla dwóch prób Welcha. Statystyka testowa posiada rozkład $t$-Studenta. Zgodnie z wynikami wcześniejszych badań dotyczących rozkładu czasu pracy w akademii (Bentley i Kyvik 2013), skupiamy się tu na rozpatrywanej w skali rocznej tygodniowej liczbie godzin zarówno w okresie, gdy odbywają się zajęcia, jak i w okresach wolnych od dydaktyki: zakładamy, że uwzględnienie 60\% dla pierwszego oraz 40\% dla drugiego okresu to dobre przybliżenie dla większości badanych systemów europejskich. Wiele wcześniejszych badań dotyczących wzorców rozkładu czasu pracy dotyczy albo pojedynczych krajów, albo jest porównawcza i deskryptywna (wyjątki to prace: Bentley i Kyvik 2013; Gottlieb i Keith 1997). W części dotyczącej ukierunkowania na role związane z kształceniem i badaniem $\mathrm{w}$ celu porównania frakcji wykorzystano test $z$ dla dwóch frakcji. Test ten pozwala porównać propor- 
cje w dwóch niezależnych próbach; statystyka testowa posiada standaryzowany rozkład normalny. Wszystkie testy zostały przeprowadzone na poziomie istotności $\alpha=0,05$. Szczegóły analizy wielowymiarowej zostały zaprezentowane poniżej w ramach analizy opartej na regresji logistycznej.

\subsection{Ograniczenia}

Istnieje lista ograniczeń odnoszących się do prezentowanych badań. Po pierwsze, wszystkie zebrane dane opierają się na deklaracjach ankietowanych, w związku z czym różnice kulturowe mogą wpłynąć na to, w jaki sposób podane zostały liczby dotyczące publikacji. Różnice w deklaracjach mogą zachodzić między krajami, dyscyplinami oraz płciami. W konsekwencji respondenci w różnym stopniu „mogą przedstawiać badaczowi nieprawdziwy obraz, na przykład mówiąc o tym, jak chcieliby, żeby sytuacja wyglądała, bardziej niż o tym, jak rzeczywiście wygląda, lub odmalowując fałszywie negatywny lub pozytywny obraz tej sytuacji” (Cohen, Manion i Morrison 2011: 404). W dobie dominacji wskaźników produktywności badawczej pytanie o liczbę publikacji może zostać również uznane za niedelikatne, a respondenci jako całość mogą podawać w odpowiedzi na nie nieprawdziwe dane (mogłyby to być jednak dane bardziej zawyżone niż zaniżone, co należy odnieść zwłaszcza do polskiego przypadku niezwykle wysokiego odsetka niepublikujących). Chociaż oparte na deklaracjach ankietowanych dane dotyczące publikacji mogą nie być doskonałe, wydają się jednak nie podlegać żadnemu systematycznemu błędowi.

Po drugie, w związku z anonimizacją zebranych danych nie byliśmy w stanie zbadać różnic między najbardziej produktywnymi naukowcami z instytucji o niższej pozycji naukowej a tymi z najbardziej prestiżowych instytucji. Po trzecie, ograniczenie bierze się z ukrytego założenia, że większość głównych pojęć wykorzystanych w międzynarodowym badaniu ankietowym ma we wszystkich systemach podobny sens. Tymczasem stosowane kategorie mogą być odmiennie rozumiane przez kadrę z różnych krajów (np. „kształcenie” i „badania” mogą być ze sobą ściśle powiązane w przypadku promotorstwa rozpraw doktorskich). Kolejne ograniczenie wiąże się ze strukturą wykorzystanego zbioru danych - w ramach analizy regresji nie można przeprowadzić rozróżnienia między publikacjami pojedynczych autorów a publikacjami wieloautorskimi oraz między publikacjami krajowymi a publikacjami międzynarodowymi (chyba że poprzez różne miary przybliżone, np. deklarowany odsetek publikacji współautorskich czy deklarowany procent publikacji wydawanych po angielsku, czyli w najbardziej popularnym języku obcym w nauce). Brakuje też w tym studium dwóch dużych systemów europejskich: francuskiego i hiszpańskiego, dla których nie zebrano danych w porównywalnym formacie. 


\section{Wyniki badań}

\subsection{Analiza dwuwymiarowa - zachowania i postawy akademickie}

Pierwsze pytanie, które warto zadać, dotyczy tego, czy najbardziej produktywni naukowcy pracują dłużej, a szczególnie czy poświęcają więcej czasu na badania, bądź też bardziej ogólnie, czy ich zachowania związane z pracą wyraźnie różnią się od zachowań pozostałych 90\% naukowców zaangażowanych w badania. Drugie pytanie dotyczy tego, czy najbardziej produktywni naukowcy są bardziej ukierunkowani na badania niż pozostali naukowcy (zgodnie z literaturą przedmiotu dotyczącą produktywności badawczej w ogóle, która pokazuje, że dłuższy czas pracy oraz większe ukierunkowanie na badania są silnie skorelowane z produktywnością badawczą; Bentley i Kyvik 2013; Shin i Cummings 2010; Ramsden 1994; Gottlieb i Keith 1997; Wanner, Lewis i Gregorio 1981).

\subsubsection{Zachowania akademickie - rozkład czasu pracy}

Badamy tu pięć przekrojów pracy akademickiej, które zostały uchwycone w bazie danych CAP/EUROAC: kształcenie, badania, służba społeczeństwu, administracja oraz inne aktywności akademickie. Średnia dla różnic w tygodniowym czasie pracy (rozpatrywanym w skali rocznej) między najbardziej produktywnymi naukowcami a pozostałymi naukowcami wynosi 6,2 godziny, wahając się od 2,2 godzin we Włoszech do 9,4 godzin w Norwegii i 10,2 godzin w Niemczech (szczegóły dotyczące rodzajów działalności akademickiej według kraju: wyniki $t$-testu dla równości średnich, najbardziej produktywni naukowcy vs. pozostali naukowcy). Innymi słowy, np. niemieccy najbardziej produktywni naukowcy, gdy porównać ich z pozostałymi (zaangażowanymi w badania, jak w całym niniejszym tekście) niemieckimi naukowcami, poświęcają średnio dodatkowych 66,3 pełnych dni roboczych na pracę na uczelni rocznie (10,2 godziny razy 52 tygodnie podzielone przez 8 godzin dziennie), a norwescy najbardziej produktywni naukowcy spędzają w pracy średnio dodatkowe 61,1 pełnych dni.

Wiemy z wcześniejszych studiów produktywności badawczej, że dłuższy czas pracy, a szczególnie więcej godzin poświęconych na badania, istotnie przyczynia się do wyższej produktywności - nasze badania pokazują z porównawczej perspektywy międzynarodowej (z wynikami o wartości $p<0,001$ ), co ów dłuższy czas oznacza dla górnych 10\% najbardziej produktywnych naukowców. Karta wstępu do elity krajowych najbardziej produktywnych naukowców różna jest jednak w zależności od kraju, ponieważ badane przez nas systemy nie są w równym stopniu konkurencyjne - w bardziej konkurencyjnych systemach (takich jak Niemcy czy 
Norwegia) najbardziej produktywni naukowcy pracują dłużej niż w mniej konkurencyjnych systemach, jeśli porównać ich z przeciętnymi naukowcami (jak w Polsce czy Portugalii).

Interesują nas tu różnice w średniej liczbie godzin pracy, szczególnie średnia liczba godzin poświęcanych na badania, między dwiema subpopulacjami w każdym kraju oraz istotność otrzymanych wyników (por. tab. 3). Nasze wyniki oparte są na dwustronnym teście $t$ zakładającym równe różnice $w$ arytmetycznych średnich, na poziomie istotności $\alpha=0,05$. Dla każdej pary o różnicy średnich istotnie różniących się od zera pojawia się w danej kolumnie symbol większej kategorii (Top dla najbardziej produktywnych naukowców oraz Pozostali dla pozostałych naukowców). Testy zostały dopasowane do wszystkich porównań parami, w obrębie danego szeregu dla każdej z wewnętrznych subtabel, z wykorzystaniem korekty Bonferroniego dla wielokrotnych porównań. Test $t$ dla dwóch średnich arytmetycznych (Top vs. Pozostali) został wykonany dla każdego kraju i każdej z pięciu typów badanej działalności akademickiej.

Tabela 3. Wyniki testu $t$ dla równości średnich - najbardziej produktywni naukowcy (Top)

vs. pozostali naukowcy (Pozostali), wszystkie kraje. Pytanie: „Biorąc pod uwagę całą aktywność zawodową, proszę wskazać, ile godzin w ciągu tygodnia przeznacza Pan(i) na każde z wymienionych poniżej zajęć w bieżącym roku akademickim?

\begin{tabular}{|l|c|c|c|c|c|c|c|c|c|c|c|}
\hline \multicolumn{1}{|c|}{ Rodzaj pracy } & AT & FI & DE & IE & IT & NL & NO & PL & PT & CH & UK \\
\hline Dydaktyka & Top & & & $\begin{array}{c}\text { Pozo- } \\
\text { stali }\end{array}$ & $\begin{array}{c}\text { Pozo- } \\
\text { stali }\end{array}$ & & Top & $\begin{array}{c}\text { Pozo- } \\
\text { stali }\end{array}$ & & Top & \\
\hline Badania & & & Top & Top & Top & Top & & Top & Top & $\begin{array}{c}\text { Pozo- } \\
\text { stali }\end{array}$ & Top \\
\hline Usługi/zlecenia & & & & & Top & & Top & & & Top & \\
\hline $\begin{array}{l}\text { Działalność } \\
\text { administracyjna }\end{array}$ & Top & Top & Top & & & Top & Top & Top & & Top & \\
\hline Inne & & & Top & Top & & & Top & & & Top & \\
\hline Lącznie & Top & Top & Top & Top & Top & Top & Top & Top & Top & Top & Top \\
\hline
\end{tabular}

Średnia na rok, 60\% w okresie, gdy prowadzone są zajęcia oraz 40\% w okresie, gdy nie ma zajęć. W tabeli przedstawiona jest grupa o istotnie większej średniej.

Źródło: opracowanie własne.

Jak widać w tabeli 3, wyniki testu potwierdzają wyniki prostych analiz opisowych - dłuższy czas pracy poświęcony na badania przez najbardziej produktywnych naukowców jest statystycznie istotny dla puli 7 krajów (Top w wersie „badania”, z wyjątkiem Szwajcarii). Ale również dla puli 7 krajów większa ilość czasu poświęconego na pracę administracyjną jest statystycznie istotna (Top w wersie „działalność administracyjna”). To samo stosuje się do godzin poświęconych na służbę społeczeństwu (3 kraje) oraz godzin poświęconych na „pozostałe” czynności 
akademickie (4 kraje). Nie zaskakuje, że z tym samym mamy do czynienia w przypadku całkowitego czasu pracy we wszystkich badanych krajach. W 3 krajach (Austria, Norwegia i Szwajcaria) istotnie dłuższy czas pracy poświęcony dydaktyce również został potwierdzony poprzez wnioskowanie. Podobnie jak w przypadku analizy opisowej (nieomawianej tu), najbardziej produktywni naukowcy poświęcają średnio więcej czasu na wszystkie działania akademickie, nie tylko na badania naukowe.

Ponadto najbardziej produktywni naukowcy jawią się niemal we wszystkich krajach jako pracujący dłużej w każdej z badanych kategorii. Na przykład niemieccy najbardziej produktywni naukowcy poświęcają więcej czasu tygodniowo na badania ( $25 \%$, czyli ok. 5 godzin więcej), pracę administracyjną (62\% lub 2 godziny więcej) oraz „pozostałe” działania akademickie (80\%, czyli ok. 2 godziny więcej). Patrząc całościowo, pracują o 10 godzin w tygodniu (czyli 25,9\%) dłużej niż pozostali niemieccy naukowcy. Jest to standardowy wzorzec pracy dla najbardziej produktywnych naukowców w większości badanych krajów - czas, który spędzają na badaniach, jest średnio o 28,5\% dłuższy, wahając się od 8,4\% we Włoszech do 31,6\% w Portugalii, 36,3\% w Irlandii i aż 48,7\% w Wielkiej Brytanii. Najbardziej produktywni naukowcy poświęcają również więcej czasu na kształcenie studentów (w krajach takich jak Norwegia i Wielka Brytania nawet 40\% czasu więcej) oraz na służbę społeczeństwu (nawet 94\% w Szwajcarii i 142\% w Norwegii). Spędzają również znacznie więcej czasu na pracach administracyjnych: średnio $40 \%$ więcej czasu, a nawet $60-80 \%$ więcej w 5 krajach. „Nauka jest czasochłonna”, a znacznie większa produkcja naukowa zajmuje dużo więcej czasu. Najbardziej produktywni naukowcy pracują (znacznie) dłużej: tydzień po tygodniu, miesiąc po miesiącu, rok po roku. Ich dłuższy całkowity czas pracy jest statystycznie istotny we wszystkich zbadanych krajach.

\subsubsection{Postawy akademickie - ukierunkowanie na kształcenie i badania naukowe}

W ujęciu statystyki opisowej, we wszystkich zbadanych krajach, udział kadry ukierunkowanej na badania w grupie najbardziej produktywnych naukowców przekracza 80\% (za wyjątkiem Portugalii, gdzie udział ten jest nieznacznie niższy); w większości krajów przekracza 90\%. Wyniki testu z dla równości frakcji przeprowadzonego dla wszystkich krajów (tab. 4) oparte są na poziomie istotności $\alpha=0.05$. Test ten został dostosowany do wszystkich porównań parami, w obrębie danego szeregu dla każdej z wewnętrznych subtabel, z wykorzystaniem korekty Bonferroniego.

Test $z$ na równość frakcji (Top vs. Pozostali) został wykonany dla każdego z krajów i każdej z czterech kategorii ukierunkowania na kształcenie lub badania. 
Tabela 4. Wyniki testu $z$ dla równości frakcji, wszystkie kraje.

Ukierunkowanie na dydaktykę/badania. Pytanie B2: „Proszę wskazać, czy w pracy akademickiej Pan(i) zainteresowania kierują się w stronę zajęć dydaktycznych, czy prowadzenia badań”, najbardziej produktywni naukowcy (Top) vs. pozostali naukowcy (Pozostali)

\begin{tabular}{|l|c|c|c|c|c|c|c|c|c|c|c|}
\hline Rola akademicka & AT & FI & DE & IE & IT & NL & NO & PL & PT & CH & UK \\
\hline $\begin{array}{l}\text { Przede wszystkim } \\
\text { zajęcia dydak- } \\
\text { tyczne }\end{array}$ & $\begin{array}{c}\text { Pozo- } \\
\text { stali }\end{array}$ & $\begin{array}{c}\text { Pozo- } \\
\text { stali }\end{array}$ & $\begin{array}{c}\text { Pozo- } \\
\text { stali }\end{array}$ & & & & $\begin{array}{c}\text { Pozo- } \\
\text { stali }\end{array}$ & $\begin{array}{c}\text { Pozo- } \\
\text { stali }\end{array}$ & & \\
\hline $\begin{array}{l}\text { Zajęcia dydaktycz- } \\
\text { ne i badania na- } \\
\text { ukowe, ze wskaza- } \\
\text { niem na pierwsze }\end{array}$ & $\begin{array}{c}\text { Pozo- } \\
\text { stali }\end{array}$ & $\begin{array}{c}\text { Pozo- } \\
\text { stali }\end{array}$ & $\begin{array}{c}\text { Pozo- } \\
\text { stali }\end{array}$ & $\begin{array}{c}\text { Pozo- } \\
\text { stali }\end{array}$ & $\begin{array}{c}\text { Pozo- } \\
\text { stali }\end{array}$ & $\begin{array}{c}\text { Pozo- } \\
\text { stali }\end{array}$ & $\begin{array}{c}\text { Pozo- } \\
\text { stali }\end{array}$ & $\begin{array}{c}\text { Pozo- } \\
\text { stali }\end{array}$ \\
\hline $\begin{array}{l}\text { Zajęcia dydak- } \\
\text { tyczne i badania } \\
\text { naukowe, ze wska- } \\
\text { zaniem na drugie }\end{array}$ & Top & Top & Top & Top & Top & & Top & Top & Top & \\
\hline $\begin{array}{l}\text { Przede wszystkim } \\
\text { badania naukowe }\end{array}$ & & & & Top & Top & & & Top & Top & & Top \\
\hline
\end{tabular}

W tabeli przedstawiona jest grupa o istotnie większej średniej.

Źródło: opracowanie własne.

Odpowiednio, dla każdej pary z różnicą dla frakcji istotnie różną od zera, symbol dla większej kategorii (Top dla najbardziej produktywnych naukowców lub Pozostali dla pozostałych naukowców) pojawia się w kolumnie.

Wyniki testu potwierdzają wyniki opisowej statystyki (pominiętej tu z racji ograniczenia objętości tekstu): ukierunkowanie na rolę badawczą (odpowiedź 3) pośród najbardziej produktywnych naukowców jest statystycznie istotne dla puli 8 krajów (Top w wersie odpowiadającym „zajęcia dydaktyczne i badania naukowe, ze wskazaniem na drugie”, bez wyjątków). Dodatkowo w puli 5 krajów silne ukierunkowanie na badania (odpowiedź 4) dla najbardziej produktywnych naukowców jest również statystycznie istotne, raz jeszcze bez wyjątków. Podział w ukierunkowaniu na role między najbardziej produktywnymi naukowcami a pozostałymi naukowcami jest jasny (a wszystkie różnice statystycznie istotne) - we wszystkich zbadanych systemach najbardziej produktywni naukowcy są bardziej ukierunkowani na badania niż pozostali naukowcy. Zainteresowanie „przede wszystkim zajęciami dydaktycznymi” w rzeczywistości wyklucza takich europejskich naukowców z klasy najbardziej produktywnych naukowców - ich udział osiąga maksymalnie $2 \% \mathrm{w}$ Irlandii, jednak w większości pozostałych krajów jest równy o\%. Co więcej, zainteresowanie „zajęciami dydaktycznymi i badaniami naukowymi, ze wskazaniem na pierwsze" również niemal wyklucza takich europejskich naukowców z tej samej klasy - ich udział wynosi ok. 3\% w Wielkiej Brytanii oraz 5-9\% w innych krajach, z dwoma wyjątkami: Polską (17,4\%) i Portugalią (21,7\%), gdzie jest on 
istotnie wyższy (należy jednak zaznaczyć, że oba systemy są ukierunkowane na kształcenie). Również udział najbardziej produktywnych naukowców, których zainteresowania dotyczą „zajęć dydaktycznych i badań naukowych, ze wskazaniem na drugie", jest podobny w całej Europie (wynosząc ok. 6o-66\%). Nasze analizy pokazują, że ukierunkowanie na rolę badawczą jest istotnym wskaźnikiem przynależności do klasy europejskiej elity badawczej - jak można było przewidzieć, koncentracja na badaniach jest niemal warunkiem koniecznym dla naukowców europejskich, a bycie ukierunkowanym na kształcenie niemal całkowicie wyklucza ich z elity badawczej.

Powyższe wyniki dotyczące rozkładu czasu pracy, jak również ukierunkowania na role związane z kształceniem/badaniem pośród bardzo produktywnych naukowców oraz pozostałych naukowców nie są jednak wielowymiarowe (wnioski $\mathrm{z}$ testu $t$ i analiz testu $z$ są niezależne od siebie). Badanie wielowymiarowych relacji wymaga podejścia opartego na modelu, uwzględniającego liczne zmienne niezależne, w tym godziny poświęcone na badania oraz ukierunkowanie badawcze. W związku z tym poniżej przedstawiamy analizę regresji logistycznej.

\subsection{Analiza oparta na regresji logistycznej}

Model analityczny służący do badania produktywności badawczej zbudowaliśmy na podstawie literatury przedmiotu, zwłaszcza badań ilościowych amerykańskich badaczy społecznych, przeprowadzonych przez Mary Frank Fox (1992: 295-297), australijskich naukowców - przez Paula Ramsdena (1994: 211-212), oraz naukowców z 10 krajów - przez Daniela Teodorescu (2000: 207). Podobnie jak Ramsden (1994) przyjęliśmy, że ,jakiekolwiek sensowne wyjaśnienie dorobku badawczego musi brać pod uwagę osobiste (indywidualne) i strukturalne (środowiskowe) czynniki, a najlepiej również interakcje zachodzące między nimi”. Niezależne zmienne zostały podzielone na ,indywidualne” i ,instytucjonalne” cechy w 8 grupach (tab. 5; numery pytań ankietowych zostały podane w nawiasach).

W tej wielowymiarowej analizie podzieliliśmy wszystkie kategorie zmiennych na dwie grupy poprzez ich zrekodowanie (dychotomizację). Zaczęliśmy od 42 osobowych i instytucjonalnych cech, podzielonych na 8 grup. Predyktory zostały następnie wprowadzone do czterostopniowego modelu regresji logistycznej (podobnie jak uczynili to Cummings i Finkelstein 2012). Współliniowość została przetestowana z wykorzystaniem odwróconej macierzy korelacji i nie stwierdzono istotnie skorelowanych ze sobą zmiennych niezależnych. Moc predykcyjna czwartego modelu (zmierzonego za pomocą $R^{2}$ Nagelkerke'a) była najwyższa dla Portugalii $(0,54)$, Wielkiej Brytanii $(0,40)$, Norwegii, Irlandii, Szwajcarii i Finlandii (ok. 0,30-0,32). Średnio modele dla wszystkich krajów wyjaśniały $32 \%$ wariancji zmiennej zależnej. Moc predykcyjna modeli produktywności badawczej oszacowana przez innych badaczy nie jest znacząco wyższa (np. średnia dla wariancji 


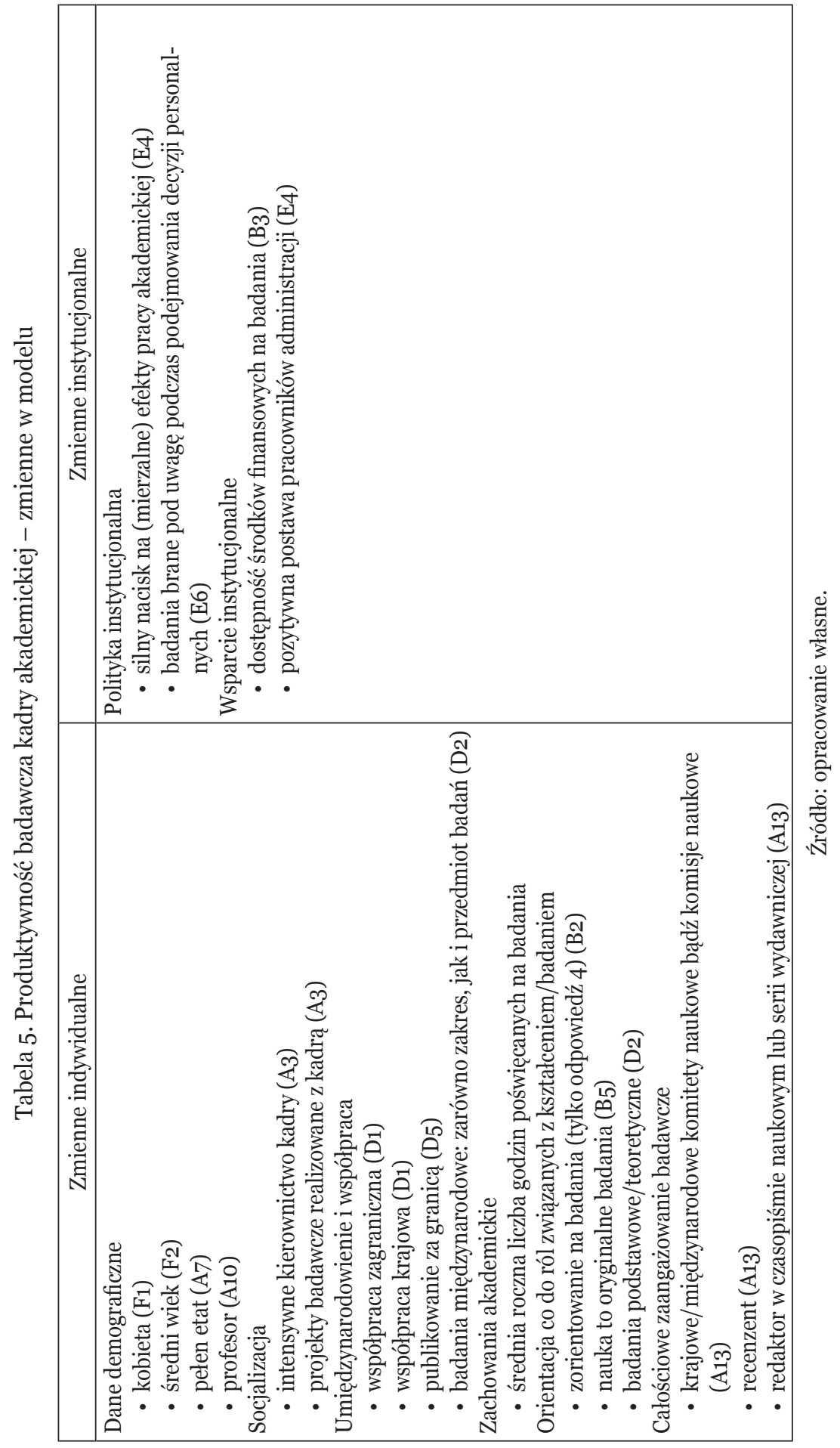




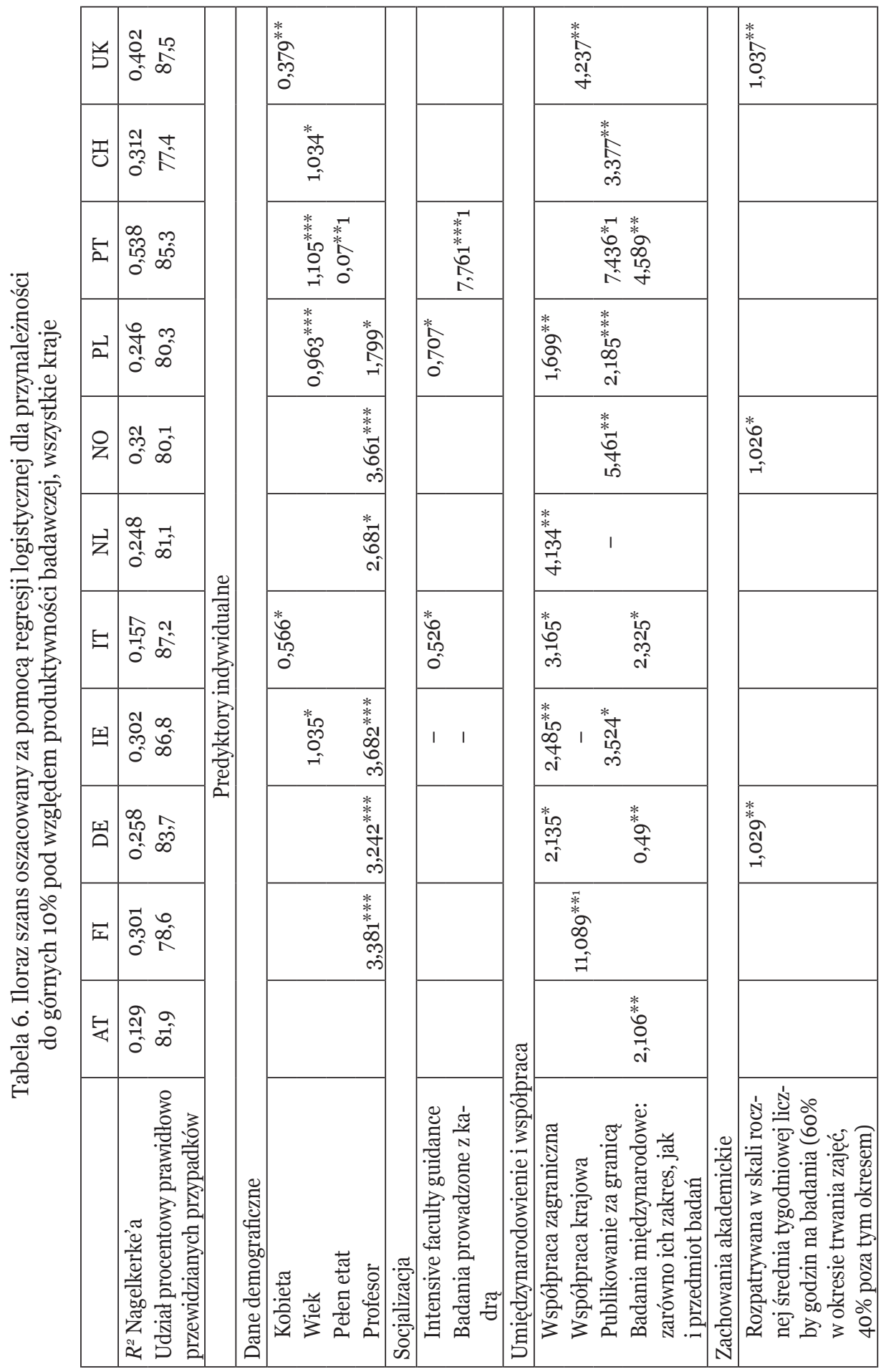




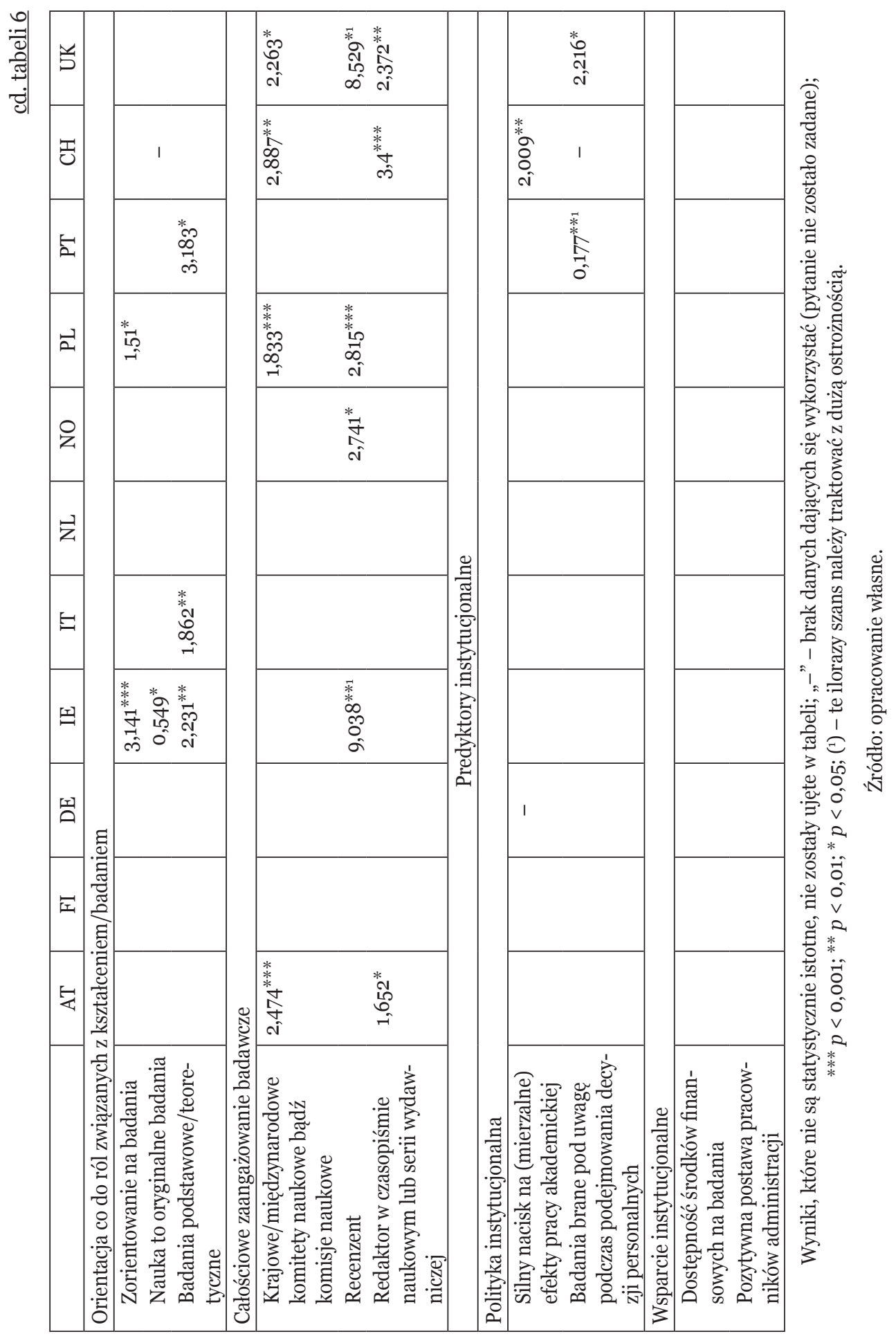


przedstawionej dla 12 krajów europejskich [Drennan i in. 2013: 129] wynosi ok. 30\%; również ok. 30\% dla 10 zbadanych w skali globalnej krajów [Teodorescu 2000: 212]). Procentowy udział poprawnie przewidzianych przypadków waha się w granicach 80-90\%, osiągając najwyższy poziom dla Wielkiej Brytanii $(87,5 \%)$, Włoch $(87,2 \%)$ i Irlandii $(86,8 \%)$ oraz nieznacznie niższy niż 80\% poziom dla Finlandii $(78,6 \%)$ i Szwajcarii $(77,4 \%)$. W tabeli 6 zaprezentowano wyniki ostatniego, czwartego modelu.

\subsubsection{Statystycznie istotne zmienne indywidualne}

Wektor zmiennych indywidualnych okazał się silniej skorelowany ze zmienną zależną niż wektor zmiennych instytucjonalnych, zarówno pod względem częstości występowania, jak i wartości parametrów modelu.

W pierwszym bloku indywidualnych predyktorów („osobistych/demograficznych”) mamy cztery zmienne: „kobieta”, „wiek”, „pełen etat” oraz „profesor”. Bycie kobietą nauki pojawiło się w równaniu zaledwie w dwóch krajach - jest to silny predyktor niestania się najbardziej produktywnym naukowcem we Włoszech, gdzie wartości wskaźnika pokazują, że kobiety nauki mają o połowę mniejsze szanse niż mężczyźni na stanie się najbardziej produktywnymi naukowcami, oraz w Wielkiej Brytanii, gdzie kobiety mają na to zaledwie $1 / 3$ szans. Jednak we wszystkich pozostałych krajach bycie mężczyzną nie jest istotnym predyktorem stania się najbardziej produktywnym naukowcem. Podczas gdy ustalenia dla Włoch są zgodne ze skupioną na płci analizą włoskich „gwiazd nauki”, przeprowadzoną przez Abramo i in. (2009), nasze wyniki są wyraźnie odmienne od rezultatów analiz opartych na regresji logistycznej, w których bycie kobietą nauki zwykle było negatywnie skorelowane z produktywnością badawczą.

Podczas gdy w większości międzynarodowych i krajowych badań wiek nie jest zmienną statystycznie istotną, nasz model pokazuje, że w czterech krajach wiek jest istotnym predyktorem wysokiej produktywności badawczej. Wzrost o jedną jednostkę (to znaczy jeden rok) w Irlandii oraz Szwajcarii zwiększa szanse na stanie się najbardziej produktywnym naukowcem o średnio 3,5\% (ceteris paribus), a w Portugalii o 10,5\%. Nie jest zaskakujące w kontekście bezprecedensowych zmian historycznych w ostatnim ćwierćwieczu w Polsce, że wzrost o jedną jednostkę w kontekście wieku w istocie zmniejsza szanse o ok. 3,5\%. Innymi słowy, średnio 10 lat różnicy pod względem wieku w Polsce obniża szanse o ok. 1/3. Przypadek Polski (w odróżnieniu od wszystkich zbadanych krajów zachodnioeuropejskich) pokazuje, że tradycyjne mechanizmy „akumulacji przewag” w karierach akademickich, połączone z wcześniejszymi mechanizmami „wzmocnienia” w nauce (Cole i Cole 1973; Zuckerman 1996; Allison 1980), wydają się nie działać w przejściowym systemie wystawionym na ogromne zmiany strukturalne - tradycyjna długoterminowa akumulacja prestiżu i zasobów, która w krajach Europy 
Zachodniej przychodzi z wiekiem, a która jest poprzedzona wcześniejszym uznaniem pracy akademickiej, nie jest tak wyraźnie dostrzegalna w Polsce.

Z kolei bycie profesorem (czy przynależność do starszej kadry) okazało się najbardziej wpływową zmienną w modelu, będącą istotnym predyktorem w 6 krajach. W 4 z nich (Finlandii, Niemczech, Irlandii i Norwegii) przynależność do wyższych szczebli hierarchii akademickiej zwiększa szanse na stanie się najbardziej produktywnym naukowcem ponad trzykrotnie, w Holandii niewiele mniej niż trzykrotnie, a w Polsce niemal dwukrotnie. To ustalenie potwierdza wnioski płynące z wcześniejszych badań produktywności - chociaż naukowcy w europejskim szkolnictwie wyższym z pewnością łatwiej otrzymują awanse na wyższe szczeble hierarchii akademickiej, jeśli są bardziej produktywni. Produktywność wpływa na bycie profesorem, ale sama ta relacja może być dwustronna (Teodorescu 2000: 214). Mówiąc ściślej, niemal wszystkie niedemograficzne zmienne niezależne w naszym modelu mogą być również zmiennymi zależnymi w osobnych analizach. Jednak, jak stwierdził Ramsden (1994: 223), „rozpoznawanie współzależności wysokiej produktywności nie oznacza, że rozpoznaliśmy relacje przyczynowo-skutkowe".

W drugim bloku indywidualnych predyktorów (socjalizacji: wprowadzenia do nauki przez starszą kadrę w okresie studiów doktoranckich i praca z kadrą przy projektach badawczych), co zaskakujące, szczególnie w kontekście amerykańskiej literatury przedmiotu, obie zmienne są albo statystycznie nieistotne, albo - jak w przypadku dwóch krajów: Polski i Włoch - w istocie zmniejszają szanse na stanie się najbardziej produktywnym naukowcem. Ogólnym wyjaśnieniem sytuacji panującej w tych dwóch systemach mogłoby być stwierdzenie, że w systemach „akademickiej oligarchii” doktoranci otrzymują wsparcie i porady ze strony kadry bardziej poprzez pracę dla niej (najczęściej jako akademicka siła robocza) niż poprzez niezależną pracę $z$ nią. Według teorii wzmocnienia (Zuckerman 1996; Fox 1983) późniejsza produktywność zależy od uzyskania wczesnego uznania pracy badawczej, w związku z czym młodzi naukowcy pracujący w warunkach intensywnego opieki ze strony kadry naukowej w specyficznym kontekście polskiego i włoskiego systemu mogą mieć mniejsze szanse na stanie się najbardziej produktywnymi naukowcami na późniejszym etapie kariery ze względu na nierozwijanie swoich niezależnych badań w wystarczającym stopniu na jej wczesnym etapie.

Trzeci blok predyktorów („umiędzynarodowienie i współpraca”) okazuje się najważniejszy w przewidywaniu wysokiej produktywności badawczej. Każda z czterech zmiennych co najmniej podwaja szanse stania się najbardziej produktywnym naukowcem. Zmienne te są następujące: „współpraca międzynarodowa”, „współpraca krajowa”, „publikowanie za granicą”, „badania o międzynarodowej skali i orientacji”. Zmienne te okazały się istotne w równaniu we wszystkich krajach poza jednym (Finlandią; relacje umiędzynarodowienia w badaniach nauko- 
wych i produktywności badawczej: Kwiek 2014b o Polsce; Kwiek 2015a o 11 krajach Europy).

Krajowa współpraca, w odróżnieniu od współpracy międzynarodowej, nie ma wpływu na wysoką produktywność badawczą w żadnym z krajów poza Wielką Brytanią. „Publikowanie za granicą” okazało się istotnym predyktorem w czterech mniejszych systemach szkolnictwa wyższego: Irlandii, Polsce, Szwajcarii i Norwegii; w związku z małymi akademickimi rynkami wewnętrznymi publikowanie międzynarodowe staje się konieczne dla piszących więcej naukowców. Również „badania o międzynarodowej skali i orientacji” zwiększają szanse w trzech krajach. Nietypowy przypadek Niemiec, gdzie zmienna ta w istocie zmniejsza szanse na stanie się najbardziej produktywnym naukowcem o połowę, może zostać wyjaśniony poprzez odwołanie się do dużego krajowego rynku akademickiego i dużej liczby niemieckojęzycznych czasopism naukowych.

W bloku „zachowań akademickich”, w przeciwieństwie do wcześniejszych wniosków z badań opartych na modelach regresji liniowej (Cummings i Finkelstein 2012: 58; Shin i Cummings 2010: 590; Drennan i in. 2013: 127), średnia tygodniowa liczba godzin przeznaczonych na badania (w skali rocznej) okazała się istotnym predyktorem jedynie w trzech krajach (Niemcy, Norwegia i Wielka Brytania): zwiększenie tygodniowo liczby godzin przeznaczonych na badania o jedną jednostkę (w skali rocznej) zwiększa szanse na stanie się najbardziej produktywnym naukowcem średnio o 2,6-3,7\% (ceteris paribus). Innymi słowy, w tych trzech krajach zwiększenie o 10 (rozpatrywanych w skali roku) godzin na badania tygodniowo prowadzi do zwiększenia szans od 1/4 do 1/3. We wszystkich pozostałych krajach znaczne inwestycje czasowe w badania nie są istotnym predyktorem stania się najbardziej produktywnym naukowcem.

Również w bloku „orientacja co do ról związanych z kształceniem/badaniem”, inaczej niż w wynikach z wcześniejszych badań opartych na modelach regresji linowej, ukierunkowanie na badania okazało się istotnym predyktorem produktywności badawczej jedynie w dwóch krajach, z $\operatorname{Exp}(B)=3,141$ dla Irlandii oraz $\operatorname{Exp}(B)=1,51$ dla Polski. We wszystkich innych krajach nie było ono istotnym predyktorem. Również postrzeganie nauki jako „oryginalnych badań” okazało się silnie współzależne z wysoką produktywnością badawczą zaledwie w jednym kraju (Irlandii, a korelacja była ujemna), zaś nacisk na „badania podstawowe/teoretyczne" zwiększał szansę na bycie najbardziej produktywnym naukowcem w zaledwie trzech krajach: Irlandii, Włoszech i Portugalii.

Analiza opisowa (zarówno w naszych analizach, jak i w: Postiglione i Jung 2013) oraz wnioskowanie statystyczne oparte na teście $t$ dla równości średnich oraz teście $z$ dla równości frakcji zaprezentowanych powyżej, zarówno w kontekście dużej liczby godzin poświęconych na badania (akademickich zachowań), jak i znacznego ukierunkowania na badania (postaw akademickich), okazują się ważnymi cechami 
najbardziej produktywnych naukowców, potwierdzając niemal powszechne w literaturze przedmiotu dotyczącej produktywności badawczej ustalenia. Zaskakujące jest jednak to, że gdy wykorzystaliśmy podejście oparte na wielowymiarowym modelu, udało nam się potwierdzić te ustalenia jedynie dla wybranych krajów.

\subsubsection{Statystycznie istotne zmienne instytucjonalne}

Wektor zmiennych istotnych w modelu różni się w zależności od kraju, jednak w całościowym ujęciu determinująca moc predyktorów z poziomu indywidualnego (bloki od 1 do 6) jest znacznie większa niż predyktorów z poziomu instytucjonalnego (bloki 7 i 8), zgodnie z wynikami wcześniejszych badań dotyczących produktywności (Ramsden 1994: 220; Shin i Cummings 2010: 588; Teodorescu 2000: 212; Cummings i Finkelstein 2012: 59). Jak w swoim niedawno wydanym tekście podsumowali Drennan i in. (2013: 128), „czynniki instytucjonalne okazują się mieć bardzo niewielki wpływ na produktywność badawczą". Jest to również ustalenie zgodne z wnioskiem dotyczącym amerykańskiej profesury, mówiącym, że „wewnętrzne motywacje”, a nie ,instytucjonalne struktury zachęt” (Finkelstein 1984: 97-98; Teodorescu 2000: 217) stymulują produktywność badawczą. Predyktory z poziomu instytucjonalnego są statystycznie istotne jedynie w przypadku dwóch krajów (Szwajcarii i Wielkiej Brytanii). Nieoczekiwanie w kontekście wcześniejszych badań (Wanner, Lewis i Gregorio 1981; Fox 1983) dwa instytucjonalne predyktory nie są statystycznie istotne w żadnym ze zbadanych krajów europejskich: „dostępność środków na badania” oraz „wspierające podejście ze strony administracji”. Może to oznaczać, że generalnie ani instytucjonalna polityka, ani instytucjonalne wsparcie nie mają istotnego znaczenia w kontekście stawania się najbardziej produktywnym naukowcem.

Co interesujące, chociaż wnioski z modeli regresji liniowej wskazują, że predyktory z poziomu instytucjonalnego dotyczące produktywności badawczej są słabe, w naszym modelu regresji logistycznej wskazują, że w istocie są statystycznie nieistotne. W szczególności środki na badania i klimat akademicki (dobre relacje między naukowcami a administracją) nie wchodzą do równań w żadnym kraju z naszego modelu. Również silne ukierunkowanie danych instytucji na wyniki jest nieistotne we wszystkich krajach oprócz Szwajcarii. Instytucjonalne zmienne w większym stopniu stosują się do polityki publicznej niż zmienne indywidualne, ponieważ „wzorce zarządzania mogą ulegać zmianie łatwiej niż indywidualne zainteresowania i postawy" (Ramsden 1994: 224; dla Polski kluczowa jest potężna rola kolegialności akademickiej i akademickich ciał kolegialnych; Kwiek 2015d z europejskiej perspektywy porównawczej). 


\section{Dyskusja}

Ustalenia poczynione na podstawie wnioskowania statystycznego ukazują dwa wyraźne międzynarodowe wzorce stosujące się do najbardziej produktywnych naukowców: większa ilość czasu poświęconego na badania (i we wszystkich kategoriach czasu pracy) oraz częstsze ukierunkowanie na badania. Jedynie w trzech krajach pozostali naukowcy rzeczywiście poświęcają więcej czasu niż najbardziej produktywni naukowcy na pracę w ramach badanych działań akademickich - jest to kształcenie studentów w Irlandii, we Włoszech i w Polsce. Wyniki z tych trzech krajów istotnie potwierdzają tezę dotyczącą antagonistycznego czy też konkurencyjnego stosunku między kształceniem a badaniami (jak twierdzi Fox [1992], która omawiała relacje „wzajemności” i „konkurencji” zachodzące między kształceniem a badaniami) na statystycznie istotnych poziomach - podczas gdy bardzo produktywni naukowcy w tych krajach poświęcają więcej czasu na badania, pozostali naukowcy poświęcają więcej czasu na kształcenie studentów. W tych krajach, jak stwierdziła Fox (1992: 303), kształcenie i badania znajdują się „we wzajemnie konfliktowym stosunku”. Najbardziej produktywni naukowcy pracują (znacznie) dłużej w ciągu tygodnia przez cały rok. Ich dłuższy całkowity czas pracy jest statystycznie istotny we wszystkich krajach. W kontekście wnioskowania statystycznego najbardziej produktywni naukowcy są również znacznie bardziej ukierunkowani na badania niż pozostali naukowcy. Najbardziej uderzająca różnica między tymi dwiema subpopulacjami jest dostrzegalna w trzech strukturalnie podobnych systemach o zbliżonym rozkładzie czasu na kształcenie/badania - w Irlandii, Polsce i Portugalii jedynie około połowa „pozostałych” naukowców jest ukierunkowana na badania. Są oni nominalnie zaangażowani w badania, ale jeśli wziąć pod uwagę ich deklarowane preferencje dotyczące ról, nie są na nie ukierunkowani. Generalnie rozkład ukierunkowania na rolę badawczą jest niemal powszechny we wszystkich badanych krajach. Zgodnie z nim bardzo produktywni naukowcy niemal powszechnie bardziej odróżniają się od „przeciętnych” naukowców w danym kraju i są bardziej podobni do najbardziej produktywnych naukowców w innych krajach.

Podczas gdy zarówno w ramach pierwszego podejścia, opartego na statystyce opisowej, jak i drugiego, bazującego na testach $t$ oraz $z$, i godziny poświęcone na badania, i ukierunkowanie na badania w znacznym stopniu charakteryzują najbardziej produktywnych naukowców, podejście oparte na wielowymiarowym modelu wykorzystującym analizę regresji nieoczekiwanie potwierdza te ustalenia jedynie dla wybranych krajów. Spośród indywidualnych zmiennych zarówno wiek, jak i przynależność do wyższych szczebli akademickiej hierarchii (bycie profesorem) są istotnymi predyktorami wysokiej produktywności badawczej. Jednak w zaska- 
kujący sposób zarówno rozpatrywane w perspektywie roku godziny poświęcane tygodniowo na badania, jak i ukierunkowanie na badania (tradycyjnie dwa najważniejsze predyktory produktywności badawczej) okazują się istotnymi predyktorami wysokiej produktywności badawczej zaledwie w odpowiednio: trzech i dwóch krajach. Jest to prawdopodobnie najbardziej kłopotliwy wynik naszego badania - podczas gdy w ramach testowania hipotez statystycznych zmienne te mają we wszystkich zbadanych systemach istotne znaczenie, $\mathrm{w}$ wielowymiarowej analizie ich rola jest dużo mniejsza, niż można by oczekiwać. Specyficzny przypadek rozkładu czasu pracy oraz zorientowania na rolę badawczą jasno pokazuje, że połączenie kilku podejść jest znacznie bardziej owocne niż poleganie na każdym $\mathrm{z}$ nich z osobna.

Istnieje również napięcie między wnioskami wyprowadzonymi z naszych 11 modeli wielozmiennowej regresji oraz pojedynczym modelem z krajami jako zmienną objaśniającą (zob. iloraz szans oszacowany dla regresji logistycznej przynależności do górnych 10\% dla produktywności badawczej, skontrolowany dla stałych efektów dla kraju). Podstawowa różnica polega na punkcie odniesienia - w jednym przypadku bardzo produktywni naukowcy zbadani zostali jako zakorzenieni w krajowych systemach, a w drugim - zbadani niezależnie od tego kontekstu. Podczas gdy w pierwszym modelu, w bloku zmiennych osobistych/demograficznych zarówno wiek, jak i płeć wchodziły do równania w kilku krajach, w pojedynczym modelu dla wszystkich europejskich naukowców oba były statystycznie nieistotne. Nieoczekiwanie, choć w pierwszym modelu praca na etacie była statystycznie nieistotna, w pojedynczym modelu zatrudnienie w pełnym wymiarze czasu zwiększało szanse na stanie się najbardziej produktywnym naukowcem przeciętnie o około połowę $[\operatorname{Exp}(B)=1,454$; ceteris paribus $]$; co więcej, podczas gdy w pierwszym modelu bycie profesorem (lub przynależność do wyższych warstw hierarchii akademickiej) zwiększało szanse w większości krajów o 170-270\%, w pojedynczym modelu zwiększało je przeciętnie o zaledwie $80 \%$. Dwie zmienne dotyczące socjalizacji do akademii nie były istotne w żadnym z dwóch modeli. Zmienne dotyczące umiędzynarodowienia i współpracy zwiększają szanse o 100-320\% (w zależności od kraju) w pierwszym modelu i zaledwie o 40-70\% w drugim modelu. Co interesujące, różnica w pojedynczym modelu zakłada, że badania międzynarodowe $\mathrm{w}$ „zasięgu i orientacji” nie zwiększają szans. W obu modelach wyższa średnia godzin przeznaczanych tygodniowo na badanie zwiększa szanse [odpowiednio o $\operatorname{Exp}(B)=1,026$ 1,037 oraz $\operatorname{Exp}(B)=1,017$; ceteris paribus]. Jednak deklarowana orientacja na badania w pierwszym modelu jest statystycznie istotna w zaledwie dwóch krajach, zaś w drugim, pojedynczym modelu jest statystycznie nieistotna. Podobnie zmienne dotyczące zaangażowania $\mathrm{w}$ badania zwiększają szanse w pierwszym modelu o 65-240\%, a w pojedynczym modelu o zaledwie 55-100\%. Jeśli chodzi o zmienne z poziomu instytucjonalnego, w pierwszym modelu są one statystycznie istotne jedynie w dwóch krajach, w pojedynczym modelu zaś są statystycznie nieistotne. 
W pojedynczym modelu, biorącym Polskę jako punkt odniesienia, bycie naukowcem niemieckim, norweskim czy austriackim zwiększa szanse zostania najbardziej produktywnym naukowcem o 200-295\%. $R^{2}$ Nagelkerke'a wynosi tu 0,185, a odsetek przypadków przewidzianych poprawnie przez model wynosi 83,80\%.

Różnice we wnioskach wyprowadzonych z dwóch różnych modeli regresji logistycznej (z różnie określanymi najbardziej produktywnymi naukowcami: dla Europy jako całości oraz osobno dla poszczególnych systemów europejskich) są mniejsze niż można by się spodziewać: w kontekście wcześniejszych badań koncentrujących się na pojedynczych krajach nieistotność zarówno wieku, jak i płci w pojedynczym modelu jest z pewnością nieoczekiwana. Wystąpienie zajmowania pozycji w wyższych warstwach hierarchii akademickiej jako predyktora wysokiej produktywności badawczej w pojedynczym modelu zgodne jest z ustaleniami wcześniejszych badań, jednak statystyczna istotność ukierunkowania na rolę badawczą w zaledwie dwóch krajach w pierwszym modelu i ich nieistotność w pojedynczym modelu może zaskakiwać. Oznacza to, że rośnie napięcie między deklarowaną orientacją na rolę badawczą a produktywnością badawczą w Europie. Podczas gdy europejscy naukowcy w coraz większym stopniu ujmują siebie jako ukierunkowanych na badania, orientacja badawcza okazuje się znacznie mniej statystycznie istotnym predyktorem stawania się najbardziej produktywnym naukowcem, niż można by oczekiwać na podstawie wcześniejszych analiz. W odróżnieniu od tego inwestycje czasu w badania okazują się istotnymi predyktorami zarówno w pierwszym modelu (w trzech krajach), jak i w pojedynczym modelu europejskim.

Występująca nieistotność predyktorów instytucjonalnych (w obu modelach) w przypadku bardzo produktywnych naukowców może stanowić wsparcie dla teorii iskry bożej w badaniach nad produktywnością (Cole i Cole 1973): bez względu na administracyjne i finansowe otoczenie instytucjonalne pewien segment kadry akademickiej - mogą to być właśnie research top performers - będzie zawsze wykazywał większy pęd w kierunku prowadzenia badań niż pozostali naukowcy. Również Peter James Bentley i Svein Kyvik (2013) w swoim globalnym badaniu 13 krajów znaleźli wsparcie dla tej teorii, bardziej niż dla konkurującej z nią teorii maksymalizacji korzyści (Stephan i Levin 1992). Jak stwierdzili Cole i Cole (1973: 71), „żeby odnosić sukcesy, naukowiec musi cechować się samodyscypliną i pracować długo i produktywnie. Taka samodyscyplina i motywacja prawdopodobnie wyjaśnia co najmniej w tym samym stopniu zróżnicowanie w sukcesach naukowych co cechy wrodzone". Najbardziej produktywni naukowcy wydają się pasować doskonale do tego opisu. Teoria akumulacji przewag (w połączeniu z teorią wzmocnienia) znajduje w niniejszym badaniu jedynie częściowe wsparcie: wiek nie jest istotnym predyktorem w większości zbadanych systemów, a przynależność do wyższych warstw hierarchii akademickiej (czy profesura), chociaż stanowi istotny predyktor $\mathrm{w}$ większości systemów, jest zwrotnie powiązana z produktywnością. 


\section{Wnioski}

W niniejszym tekście podążaliśmy kilkoma ścieżkami badawczymi. Po pierwsze, skupiliśmy się na rzadko podejmowanym w literaturze badawczej problemie bardzo produktywnych naukowców (highly productive academics). Ich rola w produkcji wiedzy we wszystkich zbadanych 11 systemach europejskich jest kluczowa: bez tych $10 \%$ badaczy produkcja naukowa w Europie zmniejszyłaby się średnio o połowę. Po drugie, zaprezentowaliśmy badanie oparte na solidnym międzynarodowym materiale ilościowym, a nie na pojedynczych badaniach krajowych, dominujących w dotychczasowej literaturze przedmiotu. Po trzecie, w odróżnieniu od bibliometrycznych badań produktywności badawczej, skupiliśmy się na akademickich postawach, zachowaniach oraz percepcjach jako predyktorach stawania się najbardziej produktywnym naukowcem (research top performer). Nasze badanie dostarcza dużego i międzynarodowego potwierdzenia nierówności w produkcji wiedzy, przedstawionych przez Lotkę (1926) i de Solla Price’a (1963). To, co moglibyśmy nazwać „zasadą 10/50”, pozostaje w mocy w całej Europie (10\% naukowców wytwarza 50\% wszystkich publikacji).

Europejska elita badawcza jest homogeniczną grupą naukowców, których wysoka produktywność badawcza jest napędzana przez strukturalnie podobne czynniki, niedające się w latwy sposób zreplikować środkami ustawodawczymi. Zmienne, które zwiększają szanse na wejście do tej grupy, pochodzą z poziomu indywidualnego, a nie instytucjonalnego. Niezależnie zaś od tego, z jakiego instytucjonalnego i krajowego kontekstu pochodzi, elita badawcza działa według tych samych wzorców dotyczących pracy akademickiej i współdzieli podobne postawy akademickie. Bardzo produktywni naukowcy są do siebie bardzo podobni z europejskiej perspektywy porównawczej i zarazem istotnie różnią się od mniej produktywnych kolegów w swoich krajach. Są gatunkiem akademickim o uniwersalnym charakterze i współdzielą niemal ten sam ciężar produkcji naukowej w całej Europie.

Nasze badania wyraźnie pokazują ważność dla całej Europy tradycyjnych generalizacji dotyczących tego, że ,jedynie niewielka część naukowców wytwarza większość nauki produkowanej przez całą wspólnotę naukową" (Cole i Cole 1973: 59). Akademicka produkcja wiedzy w Europie, podobnie jak w innych częściach świata, zawsze była poddana stratyfikacji; „niezależnie od tego, w jaki sposób ją mierzymy, mamy do czynienia z ogromnymi nierównościami w produktywności badawczej naukowców" (Allison 1980: 163), ponieważ produktywność badawcza na indywidualnym poziomie „ogromnie się różni” (Fox 1983: 286). Niniejszy tekst dostarcza zaś silnego empirycznego poparcia (pochodzącego z 11 systemów europejskich) wniosków wyprowadzanych we wcześniejszych badaniach, najczęściej zakrojonych jednak na o wiele mniejszą skalę i ograniczanych do pojedynczych krajów. 
W oparciu o bazę danych Fundacji Carnegie dotyczącą kadry akademickiej, Philip G. Altbach i Lionel S. Lewis (1996: 24) stwierdzili, jednak bez analizowania szczegółów, iż „rzeczywista produktywność jest w istocie ograniczona do mniejszości kadry akademickiej”. Paul Ramsden (1994: 223) w swoim studium produktywności badawczej opartym na ankietach zebranych od 890 naukowców z 18 australijskich instytucji doszedł do podobnych wniosków: „większość publikacji została napisana przez małą część kadry”. Podobnie Fox (1992: 296) na podstawie badania 3968 amerykańskich badaczy w naukach społecznych stwierdziła, że „niewielu ludzi wytwarza wiele artykułów, a wielu publikuje niewiele lub nic”. Zatem kluczowa zagadka badawcza brzmiała w kontekście powyższego tekstu następująco: czy jest tak również w przypadku systemów europejskich? Nasze ustalenia zgodnie pokazują, że takie wzorce rozkładu produktywności badawczej występują wyraźnie we wszystkich przebadanych europejskich systemach szkolnictwa wyższego oraz dla wszystkich pięciu głównych obszarów nauki. Polska nie różni się pod tym względem niczym od pozostałych badanych krajów europejskich - wzorzec rozkładu produkcji naukowej według typów kadry jest dokładnie taki sam; różni nas jedynie - i to bardzo, na niekorzyść - skrajnie niski poziom produktywności całości kadry. Publikujemy mało w obiegu międzynarodowym, ale przede wszystkim w ogóle średnio publikujemy bardzo mało, i w dużej części nie publikujemy wcale (Kwiek 2015e). Wyłaniający się obraz jest jednak pozytywny: polscy research top performers nie różnią się od swoich zachodnioeuropejskich kolegów tak bardzo jak pozostałe $90 \%$ kadry.

W perspektywie historycznej nasze ustalenia zgodne są z wzorcami produktywności badawczej opartymi na szacunkach dostarczonych przez Dereka Price'a w latach 60. XX wieku (w książce Mała nauka - wielka nauka), jak również w starszej pracy Alfreda J. Lotki The Frequency Distribution of Scientific Productivity (1926). „Prawo Lotki” (prawo odwrotności kwadratu produktywności) głosi, że „liczba osób wytwarzających $n$ artykułów jest proporcjonalna do 1/n2. Dla każdych 100 autorów wytwarzających pojedynczy artykuł w pewnym okresie czasu istnieje 25 tworzących dwa, 11 tworzących trzy i tak dalej" (Price 1963: 43). Podobnie w swoim badaniu amerykańskich fizyków stwierdzili Cole i Cole (1973: 218): „W oparciu o model Price'a możemy oszacować, że mniej więcej 50\% wszystkich artykułów naukowych wytwarzanych jest przez ok. 10\% naukowców". I to jest właśnie dzisiejszy rozkład produktywności w Europie: z pewnością spodziewaliśmy się możliwości potwierdzenia tej hipotezy, jednak do tej pory nie dysponowaliśmy umożliwiającymi to dużymi, międzynarodowymi danymi empirycznymi.

Nasze ustalenia empiryczne pokazują zatem, że na uniwersytetach europejskich de facto współegzystują różne segmenty „kadry akademickiej”, a profesja akademicka jest niezwykle podzielona (Kwiek 2013b) - istnieje bardzo mały segment bardzo produktywnych badaczy oraz bardzo duży segment badaczy średnio lub nisko produktywnych. Międzynarodowe podobieństwa pomiędzy produktyw- 
nymi badaczami są tak samo duże jak krajowe różnice między nimi a pozostałymi badaczami zaangażowanymi w badania. Pośród bardzo produktywnych naukowców koncentracja kobiet jest stała w całej Europie i względnie wysoka, jeśli porównywać ją z koncentracją znaną z literatury przedmiotu sprzed kilku dekad.

W tekście tym ponownie przeanalizowaliśmy „prawo Lotki” dotyczące asymetrycznego rozkładu częstotliwości publikacji w czasopismach, wskrzeszone przez Dereka Price'a, i potwierdziliśmy jego ważność w Europie. Wraz z rosnącą rolą zindywidualizowanego, konkurencyjnego finansowania w większości europejskich struktur finansowania szkolnictwa wyższego (jak również na poziomie europejskim, poprzez granty z Europejskiej Rady ds. Badań Naukowych) rola najbardziej produktywnych naukowców będzie rosła i w systemach krajowych, i w europejskim sektorze uniwersyteckim jako całości.

Rozkład produkcji wiedzy naukowej w Europie jest znacząco odchylony w stronę bardzo produktywnych naukowców. Konsekwencje dla polityki publicznej tego historycznie stałego wzorca produktywności badawczej są bardziej istotne dla tych systemów, w ramach których finansowanie badań w coraz większym stopniu oparte jest na indywidualnych grantach badawczych niż dla systemów z finansowaniem badań ukierunkowanym przede wszystkim na poszczególne instytucje (takich jak choćby Włochy; Abramo i in. 2009). Konsekwencje te różnią się w odniesieniu do konkurencyjnych i niekonkurencyjnych systemów w Europie (czyli takich, w których polityka zatrudnienia funkcjonuje w ramach modelu „awansujesz lub odchodzisz” vs. takich, w których obowiązuje model ,jeśli już jesteś w systemie - będziesz w nim na zawsze”). Głównym dylematem jest to, czy wspierać bardzo produktywnych badaczy (gdziekolwiek by nie byli ulokowani), czy najlepsze instytucje, z opcją koncentrowania bardzo produktywnych naukowców w najlepszych instytucjach, co prowadziłoby do postępującej koncentracji badań wyłącznie w wybranych, najbardziej prestiżowych instytucjach. Co więcej, wydaje się, że będzie rosło napięcie między kształceniem a badaniami w tych systemach, w których wprowadzone zostają mechanizmy konkurencyjnego finansowania na badania (przez niektórych nie bez racji nazywane „społecznym darwinizmem w najczystszej postaci"; Thornton 2012: 191).

Wnioski z naszych badań dla polityki naukowej w Europie (podobnie jak w Polsce) są kłopotliwe: jeśli systemy europejskie zrezygnowałyby ze swoich najbardziej produktywnych naukowców (górne 10\% aktywnych badawczo naukowców), np. poprzez ich wymuszoną emigrację do bardziej atrakcyjnych systemów, oferujących lepsze warunki pracy, straciłyby niemal połowę swojej krajowej produkcji naukowej. A jeśli systemy europejskie zwolniłyby dolną połowę swoich aktywnych badawczo naukowców, straciłyby 5,9\% krajowej produkcji wiedzy (a w przypadku aktywnych badawczo naukowców zatrudnionych w pełnym wymiarze czasu pracy w sektorze uniwersyteckim strata ta wyniosłaby $8,9 \%$ ). 
Wyłania się więc nowa typologia europejskiej kadry akademickiej, oparta na mierzalnym wkładzie w produkcję wiedzy: w aktywnej badawczo części kadry akademickiej występują najbardziej produktywni naukowcy, przeciętnie produktywni naukowcy (górna i dolna warstwa środkowej części populacji) oraz naukowcy nieproduktywni czy też niepublikujący (częściowo to „milczący naukowcy” Cole’a i Cole'a, których udział wśród zatrudnionych na pełen etat w sektorze uniwersyteckim waha się między mniej niż 10\% w Irlandii, Włoszech, Wielkiej Brytanii i Holandii a 43\% w Polsce). Co więcej, zarówno na instytucje szkolnictwa wyższego w ogólności, jak i uniwersytety w szczególności składają się również przedstawiciele nieaktywnej badawczo kadry, dodatkowa grupa osób nieprowadzących badań naukowych.

Nasze analizy pokazują, że zachowania i postawy akademickie najbardziej produktywnych naukowców są innym światem w porównaniu do świata zachowań i postaw średnio produktywnych naukowców (i badaczy nie zajmujących się badaniami). Pod względem produktywności badawczej nie istnieje już jednolita „profesja akademicka” (jak miało to miejsce przez ostatnie półwiecze), a jedynie „profesje” w liczbie mnogiej. „Profesje akademickie” pojawiają się w podobnym kontekście u Jürgena Endersa i Christine Musselin (2008: 127), gdy odnoszą się oni do rosnącego wewnętrznego zróżnicowania kadry, czy u Ulricha Teichlera (2014: 84), gdy bada on aktualność tradycyjnego powiązania między kształceniem a badaniami w Niemczech i ogranicza ten związek wyłącznie do grupy niemieckich „profesorów uniwersyteckich”. Postępujące rozwarstwienie kadry akademickiej w całej Europie jest nowym określeniem zachodzących obecnie procesów, a trwałość nierówności w produkcji wiedzy naukowej w różnych częściach Europy jest jednym z jej wymiarów. W niniejszym tekście zbadaliśmy specyficzną grupę bardzo produktywnych naukowców również po to, aby ukazać złożoność właściwą pojęciu „profesja akademicka”. Zdezagregowany obraz produktywności badawczej w Europie uwypukla trwałość potężnego podziału na najbardziej produktywnych naukowców i pozostałych naukowców, który był dotychczas niewystarczająco poddawany badaniom, zwłaszcza porównawczym. Obraz ten jest niemal całkowicie nieuchwytny na zagregowanych poziomach statystycznych, zwłaszcza krajowych.

Pokazujemy również istotne napięcie między wnioskami z wyników testów statystycznych a wnioskami płynącymi z regresji logistycznej. Nieoczekiwanie, podczas gdy wnioskowanie statystyczne dla zarówno dużej ilości czasu przeznaczonego na badania, jak i wysokiego stopnia ukierunkowania na badania okazuje się kluczową cechą najbardziej produktywnych naukowców, podejście oparte na wielowymiarowym modelu potwierdza te ustalenia jedynie dla wybranych krajów. W ramach weryfikacji hipotez statystycznych są to istotne zmienne we wszystkich badanych systemach, natomiast $\mathrm{w}$ analizie wielowymiarowej ich rola jest niewielka. Dochodzimy zatem do wniosku natury metodologicznej, że zastosowanie połą- 
czenia kilku podejść badawczych dostarcza lepszego pod względem empirycznym wglądu w rzeczywistość europejskiej elity badawczej niż opieranie się tylko na jednym z nich. Nie da się zlekceważyć wniosków, zgodnie z którymi ukierunkowanie na badania jest niemal niezbędne do wejścia do klasy najbardziej produktywnych naukowców w Europie, a ukierunkowanie na kształcenie studentów w istocie wyklucza europejskich badaczy z tej klasy.

Połączenie $\mathrm{w}$ prezentowanym badaniu ustaleń pochodzących $\mathrm{z}$ przeprowadzanych testów statystycznych i wielowymiarowej regresji logistycznej pozwala stwierdzić, że europejscy najbardziej produktywni naukowcy okazują się bardziej kosmopolityczni (moc umiędzynarodowienia w badaniach), znacznie ciężej pracujący (moc dużej ilości całkowitego czasu pracy i czasu przeznaczonego na badania), jak również znacznie bardziej zorientowani na badania (moc wyboru indywidualnej roli akademickiej) niż pozostali europejscy naukowcy, pomimo niezwykle zróżnicowanych krajowych systemów szkolnictwa wyższego.

Są to wnioski o znaczących implikacjach dla strategii rozwoju szkolnictwa wyższego, a szczególnie dla rekrutacji i procedur awansowych młodej kadry. Wnioski te stawiają w centrum uwagi pytania o typ młodych badaczy, jakich potrzebują europejskie - w tym również polskie - uniwersytety: czy młoda kadra, zwłaszcza w prestiżowych instytucjach, od samego początku ma być nastawiona na prowadzenie badań naukowych, czy też może być rekrutowana na potrzeby kształcenia studentów? Różnice w odpowiedziach udzielanych na to pytanie w Europie widać wyraźnie po analizowanych (Kwiek 2015e; 2015f) postawach i działaniach kadry poniżej 40. roku życia. Pytanie to jest szczególnie istotne w Polsce i powinno być zadawane i na poziomie całego systemu, i - w najlepszych ośrodkach - na poziomie każdej procedury przyjmowania do pracy i każdej procedury awansowej. Przyjmowanie do pracy w najlepszych ośrodkach naukowych osób o potencjalnie niskiej lub zerowej produktywności badawczej i utrzymywanie w nich osób o niskiej lub zerowej produktywności determinuje przyszłość polskiej nauki w konkurencyjnym systemie globalnej nauki. Suma drobnych decyzji zatrudnieniowych i awansowych podejmowanych na poziomie wydziałów powoduje nieuniknioną lawinę konsekwencji na poziomie systemu. A niska przeciętna produktywność polskiej nauki buduje od ćwierćwiecza jej przeciętnie słaby obraz w Europie i na świecie, co skutecznie odcina ją od współpracy międzynarodowej w badaniach naukowych i od międzynarodowych, przede wszystkich unijnych, konkurencyjnych środków na badania.

Najgroźniejsze dla Polski może być dość powszechne przekonanie, że nauka może funkcjonować w ramach ostrego podziału akademickich ról i zadań: z jednej strony może funkcjonować ogromna część kadry pozbawiona woli i/lub możliwości prowadzenia badań naukowych, a z drugiej mniejszość dysponująca i wolą, i możliwościami. Taki podział wywołuje bowiem przekonanie zachodniej wspólnoty badawczej, że polska nauka nie jest atrakcyjnym partnerem jako całość. Po 
upływie ćwierćwiecza od upadku komunizmu wszelkie argumenty historyczne przestają mieć znaczenie: liczy się dzisiejsze miejsce Polski w europejskich i globalnych kanałach dystrybucji wiedzy, prestiżu i zasobów finansowych. Nasze katastrofalne wyniki w konkursach organizowanych przez Europejską Radę ds. Nauki przechodzą w Polsce bez większego echa ( $\mathrm{w}$ polityce naukowej, a nie w publicystyce), ale potwierdzają niską międzynarodową atrakcyjność polskiej nauki w Europie. Na dłuższą metę statystyka wyników z ERC jest dla obrazu polskiej nauki w świecie zabójcza, ale stanowi wynik ogromnych, wieloletnich, systemowych zaniedbań. Odnosimy wrażenie, że pomimo pozytywnego wpływu reform na sposób myślenia o nauce przynajmniej części kadry akademickiej nadal mamy do czynienia z „akumulacją strat”, a nie z „akumulacją przewag”. Zaczynamy gonić systemy zachodnie, jednak bez niezbędnych, wyższych publicznych nakładów finansowych (co osłabia istnienie niezbędnych, konkurencyjnych mechanizmów finansowych); a systemy te, jak się wydaje, uciekają nam coraz szybciej, czego nie chcemy dostrzegać i na co nie chcemy reagować.

\section{Podziękowania}

Wyrażam podziękowanie za wsparcie Narodowemu Centrum Nauki, które otrzymałem w ramach projektu Maestro (DEC-2011/02/A/HS6/00183). Praca nad częścią statystyczną tekstu nie byłaby możliwa bez pomocy dr. Wojciecha Roszki z Katedry Statystyki Uniwersytetu Ekonomicznego w Poznaniu. Jestem również bardzo wdzięczny za tłumaczenie wykonane przez dr. Krystiana Szadkowskiego z UAM w Poznaniu pierwszej, krótszej wersji tego tekstu, który ukazał się jako „The European research elite: a cross-national study of highly productive academics in 11 countries" w Higher Education (OnlineFirst 14.06.2015, 1-19; DOI: 10.1007/s10734-0159910-x).

\section{Literatura}

Abramo, G., D’Angelo, C.A., Caprasecca, A. (2009). The Contribution of Star Scientists to Overall Sex Differences in Research Productivity. Scientometrics. 81(1): 137-156.

Allison, P.D. (1980). Inequality and Scientific Productivity. Social Studies of Science. 10: 163-179. Allison, P.D., Long, J.S., Krauze, T.K. (1982). Cumulative Advantage and Inequality in Science. American Sociological Review. 47: 615-625.

Allison, P.D., Stewart, J.A. (1974). Productivity Differences among Scientists: Evidence for Accumulative Advantage. American Sociological Review. 39: 596-606.

Altbach, P.G., Lewis, L.S. (1996). The Academic Profession in International Perspective. W: P.G. Altbach (red.). The International Academic Profession. Portraits of Fourteen Countries (348). Princeton: Carnegie.

Bentley, P.J., Kyvik, S. (2013). Individual Differences in Faculty Research Time Allocations Across 13 Countries. Research in Higher Education. 54: 329-348.

Cohen, L., Manion, L., Morrison, K. (2011). Research Methods in Education. New York: Routledge. 
Cole, J.R., Cole, S. (1973). Social Stratification in Science. Chicago: The University of Chicago Press.

Crane, D. (1965). Scientists at Major and Minor Universities: A Study of Productivity and Recognition. American Sociological Review. 30: 699-714.

Cummings, W.K., Finkelstein, M.J. (2012). Scholars in the Changing American Academy. New Contexts, New Rules and New Roles. Dordrecht: Springer.

Drennan, J., Clarke, M., Hyde, A., Politis, Y. (2013). The Research Function of the Academic Profession in Europe. W: U. Teichler, E.A. Höhle (red.). The Work Situation of the Academic Profession in Europe: Findings of a Survey in Twelve Countries (109-136). Dordrecht: Springer.

Enders, J., Musselin, C. (2008). Back to the Future? The Academic Professions in the 21st Century. W: Higher Education to 2030 (t. 1: Demography, 125-150). Paris: OECD.

Finkelstein, M.J (1984). The American Academic Profession. A Synthesis of Social Scientific Inquiry Since World War II. Columbus: Ohio State University Press.

Fox, M.F. (1983). Publication Productivity among Scientists: A Critical Review. Social Studies of Science. 13: 285-305.

Fox, M.F. (1992). Research, Teaching, and Publication Productivity: Mutuality Versus Competition in Academia. Sociology of Education. 65: 293-305.

Gaston, J. (1978). The Reward System in British and American Science. New York: Wiley \& Sons.

Gottlieb, E.E., Keith, B. (1997). The Academic Research-Teaching Nexus in Eight Advanced-Industrialized Countries. Higher Education. 34: 397-419.

Hagstrom, W.O. (1965). The Scientific Community. New York: Basic Books.

Katz, J.S., Martin, B.R. (1997). What Is Research Collaboration? Research Policy. 26: 1-18.

Kiewra, K. (1994). A Slice of Advice. Educational Researcher. 23(3): 31-33.

Kiewra, K.A., Creswell, J.W. (2000). Conversations with Three Highly Productive Educational Psychologists: Richard Anderson, Richard Mayer, and Michael Pressley. Educational Psychology Review. 12(1): 135-161.

Kwiek, M. (2012). Changing Higher Education Policies: From the Deinstitutionalization to the Reinstitutionalization of the Research Mission in Polish Universities. Science and Public Policy. 39: 641-654.

Kwiek, M. (2013a). From System Expansion to System Contraction: Access to Higher Education in Poland. Comparative Education Review. 57(3): 553-576.

Kwiek, M. (2013b). Knowledge Production in European Universities. States, Markets, and Academic Entrepreneurialism. Frankfurt - New York: Peter Lang.

Kwiek, M. (2014a). Structural Changes in the Polish Higher Education System (1990-2010): a Synthetic View. European Journal of Higher Education. 4(3): 266-280.

Kwiek, M. (2014b). The Internationalization of the Polish Academic Profession. A European Comparative Approach. Zeitschrift für Pädagogik. 60(5): 681-695.

Kwiek, M. (2015a). The Internationalization of Research in Europe. A Quantitative Study of 11 National Systems from a Micro-Level Perspective. Journal of Studies in International Education. 19(2): 341-359.

Kwiek, M. (2015b). Inequality in Academic Knowledge Production. The Role of Research Top Performers Across Europe. W: E. Reale, E. Primeri (red.). Universities in transition. Shifting institutional and organizational boundaries (203-230). Rotterdam: Sense. 
Kwiek, M. (2015c). The European Research Elite. A Cross-National Study of Highly Productive Academics in 11 Countries. Higher Education. OnlineFirst: 14.06.2015. doi:10.1007/s10734015-9910-x.

Kwiek, M. (2015d). The Unfading Power of Collegiality? University Governance in Poland in a European Comparative and Quantitative Perspective. International Journal of Educational Development. 43: 77-89.

Kwiek, M. (2015e). Academic Generations and Academic Work: Patterns of Attitudes, Behaviors and Research Productivity of Polish Academics after 1989. Studies in Higher Education. 40(8): 1354-1376.

Kwiek, M. (2015f). Młoda kadra: różnice międzypokoleniowe w pracy naukowej i produktywności badawczej. Czym Polska różni się od Europy Zachodniej? Nauka. 3: 51-88.

Kyvik, S. (1989). Productivity Differences, Fields of Learning, and Lotka's Law. Scientometrics. 15(3-4): 205-214.

Kyvik, S. (1990). Age and Scientific Productivity. Differences Between Fields of Learning. Higher Education. 19(1): 37-55.

Lee, S., Bozeman, B. (2005). The Impact of Research Collaboration on Scientific Productivity. Social Studies of Science. 35(5): 673-702.

Leisyte, L., Dee, J.R. (2012). Understanding Academic Work in Changing Institutional Environment. Higher Education: Handbook of Theory and Research. 27: 123-206.

Lotka, A. (1926). The Frequency Distribution of Scientific Productivity. Journal of Washington Academy of Sciences. 16: 317-323.

Marquina, M., Ferreiro, M. (2015). The Academic Profession: The Dynamics of Emerging Countries. W: W.K. Cummings, U. Teichler (red.). The Relevance of Academic Work in Comparative Perspective (179-192). Dordrecht: Springer.

Mayrath, M.C. (2008). Attributions of Productive Authors in Educational Psychology Journals. Educational Psychology Review. 20: 41-56.

Merton, R. K. (1968). The Matthew Effect in Science. Science, 159(3810): 56-63.

Patterson-Hazley, M., Kiewra, K.A. (2013). Conversations with Four Highly Productive Educational Psychologists: Patricia Alexander, Richard Mayer, Dale Schunk, and Barry Zimmerman. Educational Psychology Review. 25: 19-45.

Porter, S.R., Umbach, P.D. (2001). Analyzingfaculty workload and using multilevel modeling. Research in Higher Education. 42(2): 171-196.

Postiglione, G., Jung, J. (2013). World Class University and Asia's Top Tier Researchers. W: Q. Wang, Y. Cheng, N.C. Liu (red.). Building World-Class Universities. Different Approaches to a Shared Goal (161-180). Rotterdam: Sense.

Price, D. de Solla (1963). Little Science, Big Science. New York: Columbia University Press [wyd. polskie: Price, D. de Solla (1966). Mała nauka - wielka nauka. Tłum. P. Graff. Warszawa: $\mathrm{PWN}]$.

Prpić, K. (1996). Characteristics and Determinants of Eminent Scientists' Productivity. Scientometrics. 36(2): 185-206.

Ramsden, P. (1994). Describing and explaining research productivity. Higher Education. 28: 207-226.

Shin, J.C., Cummings, W.K. (2010). Multilevel Analysis of Academic Publishing Across Disciplines: Research Preference, Collaboration, and Time on Research. Scientometrics. 85: 581594. 
Smeby, J., Try, S. (2005). Departmental Contexts and Faculty Research Activity in Norway. Research in Higher Education. 46(6): 593-619.

Stephan, P., Levin, S. (1992). Striking the Mother Lode in Science: The Importance of Age, Place, and Time. Oxford: Oxford University Press.

Teichler, U. (2014). Teaching and Research in Germany: The Notions of University Professors. W: J.C. Shin, A. Arimoto, W.K. Cummings, U. Teichler (red.). Teaching and Research in Contemporary Higher Education. Systems, Activities and Rewards. Dordrecht: Springer.

Teichler, U., Arimoto, A., Cummings, W.K. (2013). The Changing Academic Profession. Major Findings of a Comparative Survey. Dordrecht: Springer.

Teodorescu, D. (2000). Correlates of faculty publication productivity: A cross-national analysis. Higher Education. 39: 201-222.

Thornton, M. (2012). Privatising the Public University. The Case of Law. New York: Routledge. Wanner, R.A., Lewis, L.S., Gregorio, D.I. (1981). Research Productivity in Academia: A Comparative Study of the Sciences, Social Sciences and Humanities. Sociology of Education. 54: 238-253.

Wilson, L. (1995). The Academic Man. A Study in the Sociology of a Profession. New Brunswick: Transaction Publishers.

Zuckerman, H. (1996). Scientific Elite: Nobel Laureates in the United States. New Brunswick: Transaction Publishers.

\title{
Inequalities in knowledge production - the role of highly productive academics in 11 European countries
}

\begin{abstract}
In this paper, we focus on a rare scholarly theme of highly productive academics, statistically confirming their pivotal role in knowledge production across all 11 systems studies. The upper 10 percent of highly productive academics in 11 European countries studied $(N=17,211)$, provide on average almost half of all academic knowledge production. In contrast to dominating bibliometric studies of research productivity, we focus on academic attitudes, behaviors, and perceptions as predictors of becoming research top performers across European systems. Our paper provides a (large-scale and cross-country) corroboration of the systematic inequality in knowledge production, for the first time argued for by Alfred Lotka (1926) and Derek de Solla Price (1963). We corroborate of the deep academic inequality in science and explore this segment of the academic profession. The European research elite is a highly homogeneous group of academics whose high research performance is driven by structurally similar factors, mostly individual rather than institutional. Highly productive academics are similar from a cross-national perspective and they substantially differ intra-nationally from their lower-performing colleagues.
\end{abstract}

KEYWORDS: highly productive academics, research productivity, European academic profession, stratification in science, knowledge production, European research elite

CYTOWANIE: Kwiek, M. (2015). Nierówności w produkcji wiedzy naukowej: rola najbardziej produktywnych naukowców w 11 krajach europejskich. Nauka i Szkolnictwo Wyższe. 1(45): 269-306. DOI: 10.14746/nsw.2015.1.11. 